\section{CrossMark} \&lick for updates

Cite this: New J. Chem., 2015 39,7640

Received (in Victoria, Australia) 31st March 2015,

Accepted 13th May 2015

DOI: $10.1039 / c 5 n j 00800 j$

www.rsc.org/njc

\title{
Reactivity of halfsandwich rare-earth metal methylaluminates toward potassium (2,4,6-tri- tert-butylphenyl)amide and 1-adamantylamine $\dagger$
}

\author{
Dorothea Schädle, ${ }^{a}$ Markus Enders, ${ }^{b}$ Christoph Schädle, ${ }^{a}$ Cäcilia Maichle-Mössmer, ${ }^{a}$ \\ Karl W. Törnroos ${ }^{\complement}$ and Reiner Anwander*a
}

\begin{abstract}
The equimolar reaction of potassium (2,4,6-tri-tert-butylphenyl)amide with $C p^{*} \operatorname{Ln}\left(\mathrm{AlMe}_{4}\right)_{2}\left(\mathrm{Cp} \mathrm{p}^{*}=1,2,3,4,5\right.$ pentamethyl cyclopentadienyl) yielded $\left\{\mathrm{Cp}^{*} \mathrm{Ln}\left(\mathrm{AlMe}_{4}\right)\left[\mathrm{NH}\left(\mathrm{mes}^{*}\right)\right]\right\}_{x}\left(\mathrm{Ln}=\mathrm{Y}\right.$, La; mes* $\left.=\mathrm{C}_{6} \mathrm{H}_{2} t \mathrm{Bu}_{3}-2,4,6\right)$. The treatment of $\mathrm{Cp} \mathrm{Ln}^{\star}\left(\mathrm{AlMe}_{4}\right)\left[\mathrm{NH}\left(\right.\right.$ mes $\left.\left.^{\star}\right)\right]$ with tetrahydrofuran led to intramolecular $\mathrm{C}-\mathrm{H}$ bond activation of a $t \mathrm{Bu}$ group with the formation of $\left.\mathrm{Cp} * \mathrm{YMe}\left\{\mathrm{NH}\left[\mathrm{C}_{6} \mathrm{H}_{2} t \mathrm{Bu}_{2}-2,4-\left(\mathrm{CMe}_{2} \mathrm{CH}_{2}\right)-6\right]\right\}(\mathrm{AlMe})_{2}\right)$ (thf). A similar methyl-anilide species $\mathrm{Cp}^{\mathrm{Q}} \mathrm{LuMe}\left\{\mathrm{NH}\left[\mathrm{C}_{6} \mathrm{H}_{2} t \mathrm{Bu}_{2}-2,4-\left(\mathrm{CMe}_{2} \mathrm{CH}_{2}\right)-6\right]\right\}\left(\mathrm{AlMe}_{2}\right)\left(\mathrm{Cp}^{\mathrm{Q}}=2,3,4,5\right.$-tetramethyl-1(8-quinolyl)cyclopentadienyl) with a $\mathrm{C}-\mathrm{H}$ bond activated ligand backbone formed by the reaction of $\mathrm{Cp}^{\mathrm{Q}} \mathrm{Lu}\left(\mathrm{AlMe}_{4}\right)_{2}$ and $\mathrm{K}\left[\mathrm{NH}\left(\right.\right.$ mes $\left.\left.^{*}\right)\right]$. The reactivity of $\mathrm{Cp}^{\mathrm{Q}} \mathrm{Y}\left(\mathrm{AlMe}_{4}\right)_{2}$ toward $\mathrm{H}_{2} \mathrm{NAd}$ (Ad = adamantyl) ultimately led to the methyl-amide complex $\mathrm{Cp}^{Q} \mathrm{YMe}[\mathrm{NH}(\mathrm{Ad})]\left(\mathrm{AlMe}_{3}\right)$, corroborating the presence of competing deprotonation and donor-induced methylaluminate cleavage reactions. The halfsandwich complexes $\mathrm{Cp}^{\mathrm{Q}} \mathrm{Lu}\left(\mathrm{AlMe}_{4}\right)_{2}, \mathrm{Cp} \mathrm{p}^{\star}\left(\mathrm{AlMe}_{4}\right)\left[\mathrm{NH}\left(\mathrm{mes}^{*}\right)\right], \mathrm{Cp} * \mathrm{YMe}\left\{\mathrm{NH}\left[\mathrm{C}_{6} \mathrm{H}_{2} t \mathrm{Bu}_{2}-2,4-\left(\mathrm{CMe}_{2} \mathrm{CH}_{2}\right)-6\right]\right\}\left(\mathrm{AlMe}_{2}\right)(\mathrm{thf})$, $\mathrm{Cp}^{\mathrm{Q}} \mathrm{LuMe}\left\{\mathrm{NH}\left[\mathrm{C}_{6} \mathrm{H}_{2} t \mathrm{Bu}_{2}-2,4-\left(\mathrm{CMe}_{2} \mathrm{CH}_{2}\right)-6\right]\right\}\left(\mathrm{AlMe}_{2}\right)$, and $\mathrm{Cp}^{\mathrm{Q}} \mathrm{YMe}[\mathrm{NH}(\mathrm{Ad})]\left(\mathrm{AlMe}_{3}\right)$ as well as the sideproduct $\mathrm{AlMe}_{3}\left(\mathrm{H}_{2} \mathrm{NAd}\right)$ were fully characterized by NMR/FTIR spectroscopy, elemental analysis, and X-ray crystallography.
\end{abstract}

\section{Introduction}

Halfsandwich rare-earth metal bis(hydrocarbyl) complexes ${ }^{1}$ have emerged as versatile synthesis precursors (e.g., for hydrido clusters) $)^{2}$ and eminent (pre)catalysts for polymerization reactions (e.g., fabrication of syndiotactic polystyrene). ${ }^{3}$ In 2003 , we introduced halfsandwich rare-earth metal bis(methylaluminate) complexes as thermally quite stable variants of the aforementioned bis(alkyl) derivatives. ${ }^{4}$ Upon cationization with fluorinated phenylborane/borate reagents complexes $\mathrm{Cp}^{\mathrm{R}} \mathrm{Ln}\left(\mathrm{AlMe}_{4}\right)_{2}$ promote the living 1,4-trans-selective polymerization of isoprene (synthetic gutta-percha) ${ }^{5}$ and butadiene. ${ }^{6}$ Such catalyst activation proceeds via well-established protonolysis and alkyl abstraction pathways. ${ }^{7}$ The feasibility of protonolysis reactions was also demonstrated for the syntheses of metallocenes ${ }^{8}$ as well as silica-grafted

\footnotetext{
${ }^{a}$ Institut für Anorganische Chemie, Universität Tübingen, Auf der Morgenstelle 18, D-72076 Tübingen, Germany. E-mail: reiner.anwander@uni-tuebingen.de; Fax: +49707129 35271; Tel: +4970712972069

${ }^{b}$ Anorganisch-Chemisches Institut, Universität Heidelberg, Im Neuenheimer Feld 270, D-69120 Heidelberg, Germany ${ }^{c}$ Department of Chemistry, University of Bergen, Allégaten 41, N-5007 Bergen, Norway

$\dagger$ Electronic supplementary information (ESI) available. CCDC 1055068-1055073. For ESI and crystallographic data in CIF or other electronic format see DOI: $10.1039 / \mathrm{c} 5 \mathrm{nj} 00800 \mathrm{j}$
}

hybrid materials and respective alkoxide/siloxide model complexes. ${ }^{9}$ Furthermore, complexes of the type $\mathrm{Cp}^{\mathrm{R}} \operatorname{Ln}\left(\mathrm{AlMe}_{4}\right)_{2}$ were successfully applied in $\mathrm{C}-\mathrm{H}$ bond activation protocols giving access to the first structurally characterized rare-earth metal methylidyne ${ }^{10}$ and methylidene complexes. ${ }^{11,12}$ In the following, we adopted the concept of alkylaluminate-based organoaluminium-assisted deprotonation for the synthesis of rare-earth metal imide complexes. ${ }^{13}$ One major finding was that the superbulky monanionic $\mathrm{Tp}^{t \mathrm{Bu}, \mathrm{Me}}$ (= hydrotris(3-tert-butyl-5-methyl-pyrazolyl)borate) ligand can afford monolanthanide derivatives of the type $\left[\left(\mathrm{Tp}^{t \mathrm{Bu}, \mathrm{Me}}\right)\right.$ $\left.\mathrm{Ln}(\mathrm{NAr})\left(\mathrm{AlHMe}_{2}\right)\right]\left(\mathrm{Ar}=\mathrm{C}_{6} \mathrm{H}_{3} \mathrm{Me}_{2}-2,6\right)^{14}$ and $\left[\left(\mathrm{Tp}^{t \mathrm{Bu}, \mathrm{Me}}\right) \mathrm{Ln}(\mathrm{NR})-\right.$ $\left.\left(\mathrm{AlMe}_{3}\right)\right](\mathrm{Ln}=\mathrm{Y}, \mathrm{Ho} ; \mathrm{R}=t \mathrm{Bu}$, adamantyl $) .{ }^{15}$ The isolation of rare-earth metal complexes $\left[\left(\mathrm{Tp}^{t \mathrm{Bu}, \mathrm{Me}}\right) \mathrm{Ln}=\mathrm{NR}(\mathrm{dmap})\right](\mathrm{Ln}=\mathrm{Y}$, $\left.\mathrm{Ar}=\mathrm{C}_{6} \mathrm{H}_{3} \mathrm{Me}_{2}-2,6 ; \mathrm{Ln}=\mathrm{Lu}, \mathrm{Ar}=\mathrm{C}_{6} \mathrm{H}_{3}\left(\mathrm{CF}_{3}\right)_{2}-3,5\right)$ with a terminally bonded imido ligand was achieved by an aluminium-free synthesis procedure. ${ }^{16}$ Prior to our studies it has been shown that the deprotonation of rare-earth metal anilide complexes with organoaluminium or alkyl lithium reagents $(\text { e.g. Scheme } 1, \mathbf{V})^{17}$ is a viable strategy toward $\mathrm{Ln}^{\mathrm{III}}$ imide complexes. ${ }^{17,18}$

Given the plethora of group 4 imide complexes, ${ }^{19}$ rare-earth metal imide chemistry is still in its infancy. ${ }^{20}$ Mountford and coworkers examined the efficiency of deprotonation reactions utilizing, e.g. $\mathrm{TiCl}_{4}$ or $\mathrm{Ti}\left(\mathrm{NMe}_{2}\right)_{4}$ in amine elimination and transamination/transimination reactions, respectively. ${ }^{21}$ It is noteworthy that such synthesis protocols are not applicable for the rare-earth metals (vide infra). 

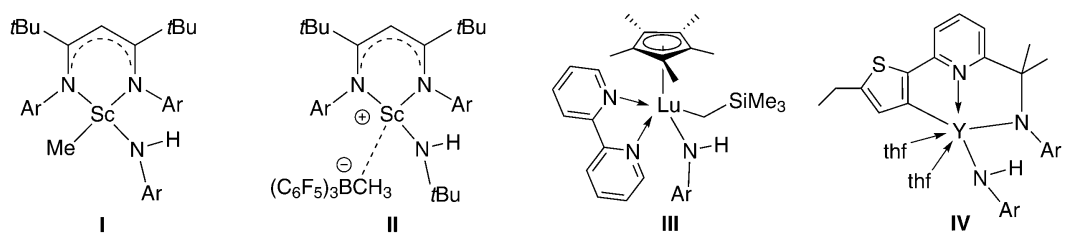

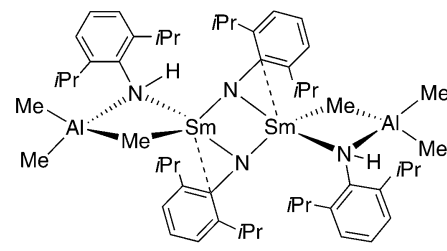

V

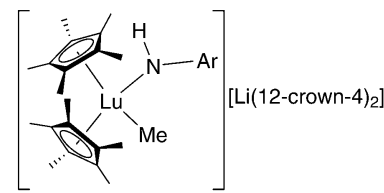

VI

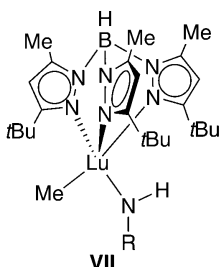

$\mathrm{R}=\mathrm{tBu}$, adamanty

Scheme 1 Structurally characterized rare-earth metal complexes with the amido NH functionality adjacent to Ln-C(alkyl). ${ }^{17,22-24}$

Based on the successful synthesis of rare-earth metal imide complexes exploiting the synergistic effect associated with organoaluminium moieties and the superbulky monanionic $\mathrm{Tp}^{t \mathrm{Bu}, \mathrm{Me}}$, we have now set out to explore cyclopentadienylsupported rare-earth metal bis(tetramethylaluminate)s as potential precursors for imide complexes. Herein, we describe the reactivity of $\mathrm{Cp}^{*} \mathrm{Ln}\left(\mathrm{AlMe}_{4}\right)_{2}$ and $\mathrm{Cp}^{\mathrm{Q}} \mathrm{Ln}\left(\mathrm{AlMe}_{4}\right)_{2}$ toward potassium (2,4,6tri-tert-butylphenyl)amide and 1-adamantylamine, respectively $\left(\mathrm{Cp}^{*}=1,2,3,4,5\right.$-pentamethylcyclopentadienyl, $\mathrm{Cp}^{\mathrm{Q}}=2,3,4,5-$ tetramethyl-1-(8-quinolyl)cyclopentadienyl). Overall, this study discloses a better understanding of why steric/electronic mismatches in isolable mixed amide-alkyl complexes hamper their conversion into the respective imide derivatives. ${ }^{22-24}$ As compiled in Scheme 1, various mixed amide-alkyl complexes (including cationic (II $)^{22 b}$ and anionic rare-earth metal entities (VI) ${ }^{22 C}$ ) have been accessed in the presence of a stabilizing N-donor $\left(\mathbf{I},{ }^{22 a} \mathbf{I I},{ }^{22 b}\right.$ IV ${ }^{23}$ VIII, ${ }^{15}$ ) and cyclopentadienyl ancillary ligands $\left(\mathbf{I I I},{ }^{24} \mathbf{V I}^{22} \mathrm{c}\right.$.

\section{Results and discussion}

\section{Reactivity of $\mathrm{Cp}^{*} \operatorname{Ln}\left(\mathrm{AlMe}_{4}\right)_{2}(1)$}

The salt-metathesis reaction of half-sandwich complexes $\mathrm{Cp}^{*} \operatorname{Ln}\left(\mathrm{AlMe}_{4}\right)_{2}(\mathrm{Ln}=\mathrm{Y}(\mathbf{1 a}), \mathrm{La}(\mathbf{1 b}))^{8}$ with 1 equivalent potassium (2,4,6-tri-tert-butylphenyl)amide, $\mathrm{K}\left[\mathrm{NH}\left(\mathrm{mes}^{*}\right)\right]$, in $n$-hexane at ambient temperature yielded $\left\{\mathrm{Cp}^{*} \operatorname{Ln}\left(\mathrm{AlMe}_{4}\right)\left[\mathrm{NH}\left(\mathrm{mes}^{*}\right)\right]\right\}_{x}(\mathrm{Ln}=\mathrm{Y}$ (2a), $x=2$; Ln $=$ La $(\mathbf{2 b}))$ in $83 \%$ and $87 \%$ yield, respectively (Scheme 2). Rather surprisingly, the reaction came to a halt at the heteroleptic amide-methylaluminate complex and the subsequent deprotonation of the $\mathrm{NH}$ anilido functionality did not occur. The mixed amide-imide complex $\left[\mathrm{Sm}(\mathrm{NHAr})\left(\mathrm{AlMe}_{3}\right)(\mathrm{NAr})\right]_{2}{ }^{17}$ is the only other example featuring an $\mathrm{NH}(\mathrm{Ar})$ ligand adjacent to an organoaluminium moiety (V, Scheme 1$)$. The latter complex $\mathbf{V}$ was obtained from $\mathrm{Sm}(\mathrm{NHAr})_{3}$ and $\mathrm{AlMe}_{3}$. For comparison, excess addition of trimethylaluminium to $\mathrm{Nd}(\mathrm{NHPh})_{3}(\mathrm{Ph}=$ phenyl) led to a completely deprotonated imide complex $\left[\mathrm{Nd}\left(\mathrm{AlMe}_{4}\right)_{2}(\mathrm{NPh})\left(\mathrm{AlMe}_{2}\right)\right]_{2}$ and co-product $\left[(\mathrm{NHPh}) \mathrm{AlMe}_{2}\right]_{3}$ formed by anilido-methyl exchange. ${ }^{18 a}$ Aryloxide derivatives $\left[\mathrm{Cp}^{*} \operatorname{Ln}\left(\mathrm{AlMe}_{4}\right)\left(\mathrm{OAr}^{t \mathrm{Bu}, \mathrm{R}}\right)\right]$ $(\mathrm{Ln}=\mathrm{Lu}, \mathrm{Y} ; \mathrm{R}=\mathrm{H}, \mathrm{Me})$ reminiscent of complexes 2 were

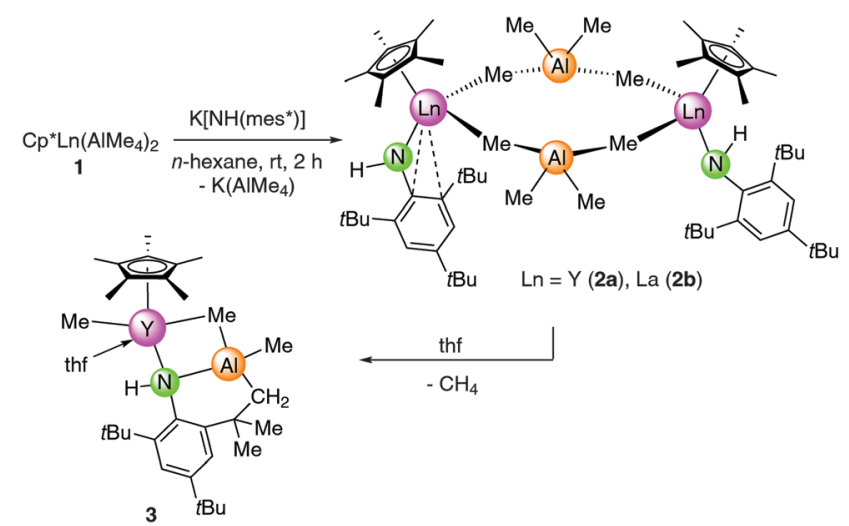

Scheme 2 Synthesis of anilide complexes 2 and 3.

obtained by the treatment of $\left[\mathrm{Cp}^{*} \operatorname{Ln}\left(\mathrm{OAr}^{t \mathrm{Bu}, \mathrm{R}}\right)_{2}\right]$ with an excess of trimethylaluminium. ${ }^{9 b}$

Colourless crystals of 2 were sparingly soluble in aliphatic hydrocarbons but soluble in aromatic solvents. The ${ }^{1} \mathrm{H}$ NMR spectra of complexes 2 show one set of signals for the $\mathrm{Cp}^{*}$, $\mathrm{NH}\left(\mathrm{mes}^{*}\right)$, and $\mathrm{AlMe}_{4}$ ligands. The five methyl groups of the $\mathrm{Cp}^{*}$ ring appear as one singlet at 1.89 and $2.04 \mathrm{ppm}$ in complexes $2 \mathrm{a}$ and $2 \mathbf{b}$, respectively. The signals at $5.05 \mathrm{ppm}(2 \mathrm{a})$ and $5.83 \mathrm{ppm}$ (2b) can be assigned to the $\mathrm{NH}$ functionalities. The metal-bonded methyl groups show one sharp signal at ambient temperature $\left(2 \mathbf{a},-0.33 \mathrm{ppm},{ }^{2} \mathrm{~J}_{\mathrm{YH}}=2.5 \mathrm{~Hz} ; 2 \mathbf{b},-0.43 \mathrm{ppm}\right)$, which implies a rapid exchange between bridging and terminal methyl groups. For yttrium complex 2a signal splitting of the bridging and terminal methyl groups into two broad singlets at $-0.37 \mathrm{ppm}$ and $-0.11 \mathrm{ppm}$ occurred at approximately $-90{ }^{\circ} \mathrm{C}$. Variabletemperature ${ }^{1} \mathrm{H}$ NMR studies on lanthanum complex $2 \mathbf{b}$ did not reveal any signal splitting at temperatures from +25 to $-90{ }^{\circ} \mathrm{C}$ indicative of a higher mobility of the La-( $\left(\mathrm{AMe}_{4}\right)$ moiety.

Single crystals of $\left\{\mathrm{Cp}^{*} \mathrm{Y}\left(\mathrm{AlMe}_{4}\right)\left[\mathrm{NH}\left(\mathrm{mes}^{*}\right)\right]\right\}_{2}$ (2a) were grown from saturated $n$-hexane solutions at $-35{ }^{\circ} \mathrm{C}$. The X-ray crystallographic analysis revealed a structural motif as found in the solidstate structure of $\left[\mathrm{Cp}^{*}{ }_{2} \operatorname{Ln}\left(\mathrm{AlMe}_{4}\right)\right]^{8,25}(\mathrm{Ln}=\mathrm{Y}, \mathrm{La}, \mathrm{Sm})$ with the yttrium metal centers being bridged by two $\mu_{2}-\eta^{1}: \eta^{1}$ coordinated $\mathrm{AlMe}_{4}$ ligands $\left(\mathrm{Y} 1-\mathrm{C} 1-\mathrm{Al} 1=174.8(2)^{\circ} ; \mathrm{Y} 2-\mathrm{C} 3-\mathrm{Al} 1=169.3(2)^{\circ}\right)$, 


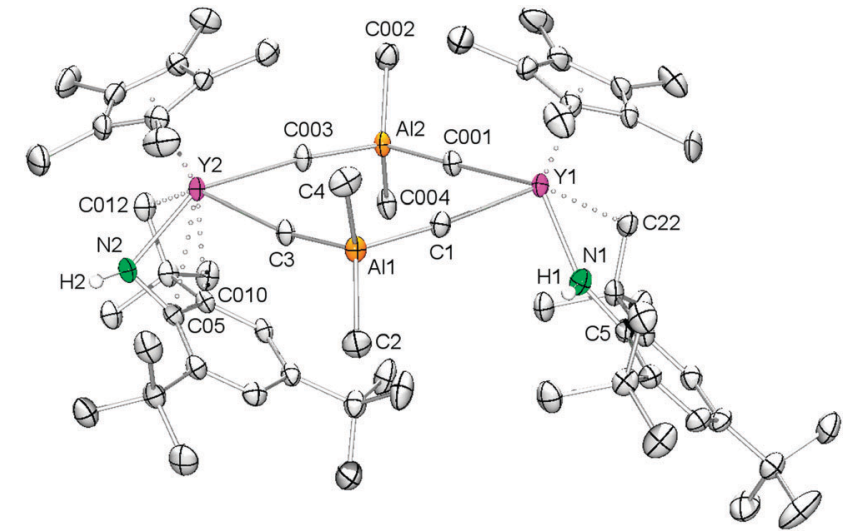

Fig. 1 Molecular structure of $\mathbf{2 a}$. Atoms are represented by atomic displacement ellipsoids set at the $50 \%$ level. Solvent molecules ( $n$-hexane) and hydrogen atoms except for the $\mathrm{NH}$ protons are omitted for clarity. Selected bond distances [Å] and angles [deg]: Y1-N1 2.186(4), Y2-N2 2.226(3), Y1-C1 2.680(7), Y1-C001 2.653(4), Y2-C3 2.685(4), Y2-C003

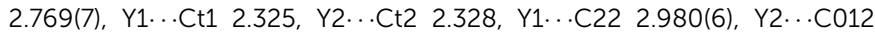

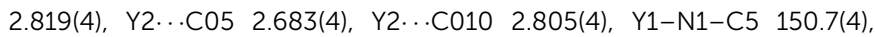
Y2-N2-C05 93.1(3), Y1-C1-Al1 174.8(2), Y2-C3-Al1 169.3(2).

while the $\mathrm{Cp}^{*}$ and amido ligands are coordinated terminally (Fig. 1). The $\mathrm{NH}\left(\mathrm{mes}^{*}\right)$ ligands exhibit two distinct coordination modes with the most striking difference being the $\mathrm{Y}-\mathrm{N}($ amide $)-$ $\mathrm{C}(\operatorname{aryl})$ bond angles of $\mathrm{Y} 1-\mathrm{N} 1-\mathrm{C} 5=150.7(4)^{\circ}$ and $\mathrm{Y} 1-\mathrm{N} 2-\mathrm{C} 05=$ 93.1(3) . The Y-N(amido) bond lengths of 2.186(4) $\AA$ and 2.226(3) $\AA$ are in the expected range. ${ }^{26}$ The bent amido ligand features additional Ln $\cdots$ arene interactions involving two short contacts to the ipso and ortho carbon atoms of the aryl ring. Both amido ligands show secondary interactions with the Y(III) center through one of the methyl groups of the tert-butyl substituents.

Attempts to synthesize putative $\mathrm{Cp}^{*} \mathrm{Ln}=\mathrm{Nmes}^{*}$ from 2 a via Lewis base-induced methane elimination, as described earlier for other alkyl-amide complexes, were not successful. ${ }^{27}$ Upon addition of thf to 2 a no visual changes were observed, meaning that the mixture remained as a yellow solution. However, evaporation of the solvent, drying in vacuo, and recrystallization of the residue from $n$-hexane produced single crystals of complex 3, revealing $\mathrm{AlMe}_{4}$ cleavage and $\mathrm{C}-\mathrm{H}$ bond activation of one of the tert-butyl groups (Scheme 2, Fig. 2). The generated monomeric complex is 7-coordinate by the $\mathrm{C}-\mathrm{H}$ activated primary amido ligand, $\left(\mu_{2}-\mathrm{Me}\right) \operatorname{AlMe}\left\{\mathrm{NH}\left[\mathrm{C}_{6} \mathrm{H}_{2} t \mathrm{Bu}_{2}-2,4-\left(\mathrm{CMe}_{2} \mathrm{CH}_{2}\right)-6\right]\right\}$, a $\eta^{5}-\mathrm{Cp}^{*}$ ligand, a thf molecule, and a terminal methyl group. The Y-N(amido) bond length of 2.489(2) $\AA$ is significantly elongated compared to $2 \mathrm{a}(\mathrm{Y}-\mathrm{N}($ amido $)=2.186(4) / 2.226(3) \AA)$, which is due to the formation of a four-membered $\mathrm{Y}-\left(\mu_{2}-\mathrm{Me}\right)-$ $\mathrm{Al}-\mathrm{N}$ metallacycle. This four-membered metallacycle is fused via the Al-N bond to a six-membered metallacycle, which itself is annulated to the (anilido)phenyl ring. The $\mathrm{Y}-\mathrm{C}$ bond lengths differ markedly with the terminal $\mathrm{Y}-\mathrm{C}\left(\mathrm{CH}_{3}\right)$ distance being quite short (2.406(3) ̊) similar to the diketiminate complex (L) $\mathrm{YMe}_{2}$ $\left(\mathrm{L}=\mathrm{MeC}\left(\mathrm{N}\left(\mathrm{C}_{6} \mathrm{H}_{3} \mathrm{Pr}_{2}-2,6\right)\right) \mathrm{CHC}(\mathrm{Me}) \mathrm{NCH}_{2} \mathrm{CH}_{2} \mathrm{~N}(\mathrm{Me}) \mathrm{CH}_{2} \mathrm{CH}_{2} \mathrm{NMe}_{2}\right)$ (av. 2.433 $\AA^{28}$ and hydrotris(pyrazolyl)borate compound $\left(\mathrm{Tp}^{t \mathrm{Bu}, \mathrm{Me}}\right.$ )$\mathrm{YMe}\left(\mathrm{AlMe}_{4}\right)\left(\mathrm{Y}-\mathrm{C}\left(\mathrm{CH}_{3}\right)=2.382(3) \AA ; \mathrm{Y}-\mathrm{C}\left(\mu_{2}-\mathrm{CH}_{3}\right)=2.715(3) \AA\right),{ }^{29}$ while the $\mathrm{Y}-\mathrm{C}\left(\mu_{2}-\mathrm{CH}_{3}\right)(2.827(3) \AA)$ distance is relatively long in

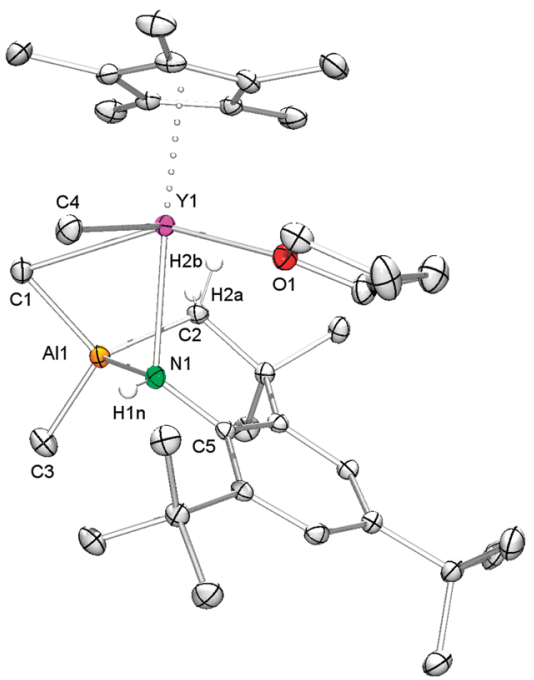

Fig. 2 Molecular structure of 3 . Atoms are represented by atomic displacement ellipsoids set at the $30 \%$ level. Hydrogen atoms except for the $\mathrm{NH}$ proton and the methylene protons are omitted for clarity. Selected bond distances $[\AA \AA]$ and angles [deg]: Y1-C1 2.827(3), Y1-C4 2.406(3), Y1-N1 2.489(2), Y1-O1 2.375(2), Y1...Ct1 2.384, Y1‥Al1 3.0705(9), Al1-N1 1.902(2), Al1-C1 2.014(3), Al1-C2 1.985(3), Al1-C3 1.962(3), Y1-N1-C5 123.6(2), C1-Y1-C4 80.4(1), C1-Y1-O1 151.64(8), C4-Y1-O1 92.38(9), N1-Y1-Ct1 162.03, Y1-C1-Al1-N1 39.6(1).

comparison to 2a (av. $2.697 \AA$ ) and $\left[\mathrm{Cp}_{2}^{*} \mathrm{Y}\left(\mathrm{AlMe}_{4}\right)\right]_{2}^{25 a}$ (2.66 ̊̊). Unfortunately, ${ }^{1} \mathrm{H}$ and ${ }^{13} \mathrm{C}$ NMR spectroscopic investigations were hampered by fast decomposition of the product.

\section{Reactivity of $\mathrm{Cp}^{\mathrm{Q}} \mathrm{Ln}\left(\mathrm{AlMe}_{4}\right)_{2}$ (4 and 6)}

In order to enhance the steric pressure at the rare-earth metal center during the tetramethylaluminate displacement we decided to use the $\mathrm{N}$-donor substituted bis(tetramethylaluminate) precursor $\mathrm{Cp}^{\mathrm{Q}} \mathrm{Ln}\left(\mathrm{AlMe}_{4}\right)_{2}(\mathrm{Ln}=\mathrm{Y}, \mathrm{Lu})$. The presence of the rigid quinolyl functionality was anticipated to minimize any undesired $\mathrm{C}-\mathrm{H}$ bond activation at the $\mathrm{N}$-donor substitutent. ${ }^{32} \mathrm{Cp}^{\mathrm{Q}} \mathrm{Lu}\left(\mathrm{AlMe}_{4}\right)_{2}$ was prepared by a slightly modified procedure than described earlier for the yttrium and lanthanum congeners. ${ }^{33}$

Accordingly, quinolyl-substituted half-sandwich complex $\mathrm{Cp}^{\mathrm{Q}} \mathrm{Lu}\left(\mathrm{AlMe}_{4}\right)_{2}$ (4) was obtained via protonolysis of homoleptic $\mathrm{Lu}\left(\mathrm{AlMe}_{4}\right)_{3}$ with $\mathrm{HCp}^{\mathrm{Q}}$. Brown powdery 4 is readily soluble in toluene, but only sparingly soluble in $n$-hexane. The ${ }^{1} \mathrm{H}$ NMR spectrum of 4 in $\mathrm{C}_{6} \mathrm{D}_{6}$ at ambient temperature shows one signal for the $\mathrm{AlMe}_{4}$ ligands at $-0.13 \mathrm{ppm}$, two singlets for the cyclopentadienyl methyl groups at 1.78 and $2.02 \mathrm{ppm}$ and one set of signals for the quinolyl moiety.

Single crystals of $\mathbf{4}$ suitable for X-ray structure analysis were grown from a toluene- $n$-hexane mixture at $-35{ }^{\circ} \mathrm{C}$. As for the yttrium and lanthanum congeners ${ }^{33}$ the $\mathrm{Cp}^{\mathrm{Q}}$ ligand binds to the metal center in an $\eta^{5}$ fashion through all five carbon atoms and via the quinolyl nitrogen atom (Fig. 3). Not surprisingly, in the sterically more congested lutetium complex one of the $\mathrm{AlMe}_{4}$ ligands coordinates in an $\eta^{1}$ fashion while the other exhibits the usually observed planar $\eta^{2}$ coordination mode (Lu1-C24-Al2-C23 $\left.=5.16(8)^{\circ}\right)$, accounting for an overall heptacoordinate $\mathrm{Lu}(\mathrm{III})$ metal center. Such $\eta^{1}$ coordination mode of 


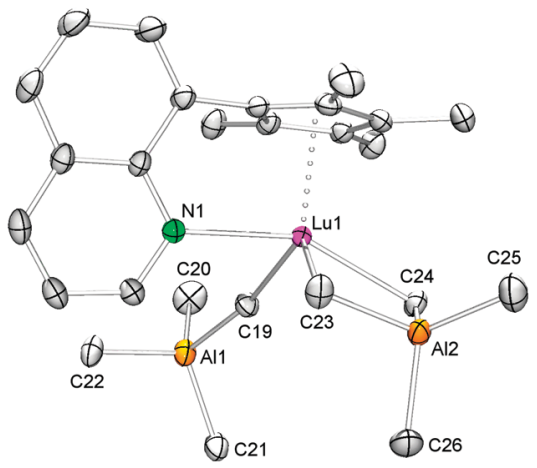

Fig. 3 Molecular structure of 4 . Atoms are represented by atomic displacement ellipsoids set at the $50 \%$ level. Hydrogen atoms are omitted for clarity. Selected bond distances [Å] and angles [deg]: Lu1-N1 2.417(1), Lu1-C19 2.539(2), Lu1-C23 2.485(2), Lu1-C24 2.524(2), Lu1…Ct1 2.247, Lu1 ...Al1 4.5877(6), Lu1...Al2 3.0296(5), Al1-C19 2.081(2), Al1-C20/21/22 1.991(2)/2.001(2)/1.997(2), Al2-C23 2.081(2), Al2-C24 2.069(2), Al2-C25/ 26 1.964(2)/1.968(2), N1-Lu1-Ct1 96.57, C19-Lu1-Ct1 116.25, C23-Lu1Ct1 120.30, C24-Lu1-Ct1 110.86, Lu1-C19-Al1 166.51(9), Lu1-C23-Al2 82.63(6), Lu1-C24-Al2 81.87(6), Lu1-C24-Al2-C23 5.16(8).

the $\mathrm{AlMe}_{4}$ ligand with an almost linear $\mathrm{Lu}-\mathrm{C}\left(\mu-\mathrm{CH}_{3}\right)-\mathrm{Al}$ bond angle of $166.51(9)^{\circ}$ has been observed before in $\left(\mathrm{Tp}^{t \mathrm{Bu}, \mathrm{Me}}\right) \mathrm{YMe}\left(\mathrm{AlMe}_{4}\right)$ $\left(\mathrm{Y} 1-\mathrm{C}\left(\mu-\mathrm{CH}_{3}\right)-\mathrm{Al}=161.0(1)^{\circ}\right)^{29}$ and $\left[\left(\mathrm{ArNMe}_{2}\right)_{2} \mathrm{NC}_{5} \mathrm{H}_{3}\right] \mathrm{La}\left(\mathrm{AlMe}_{4}\right)($ thf $)$ $\left.\left(\mathrm{Ar}=\mathrm{C}_{6} \mathrm{H}_{3} \mathrm{iPr}_{2}-2,6, \mathrm{La} 1-\mathrm{C}\left(\mu-\mathrm{CH}_{3}\right)-\mathrm{Al}=165.0(4)\right)^{\circ}\right),{ }^{30}$ supported by sterically demanding tridentate $(\mathrm{NNN})^{n-}$ ligands $(n=1,2)$.

Interestingly, the salt metathesis reaction of $\mathrm{Cp}^{\mathrm{Q}} \mathrm{Lu}\left(\mathrm{AlMe}_{4}\right)_{2}$ (4) and $\mathrm{K}\left[\mathrm{NH}\left(\mathrm{mes}^{*}\right)\right]$ led to complex $\mathrm{Cp}^{\mathrm{Q}} \mathrm{LuMe}\left\{\mathrm{NH}\left[\mathrm{C}_{6} \mathrm{H}_{2} t \mathrm{Bu}_{2}\right.\right.$ 2,4- $\left.\left.\left(\mathrm{CMe}_{2} \mathrm{CH}_{2}\right)-6\right]\right\}\left(\mathrm{AlMe}_{2}\right)$ (5) (Scheme 3) revealing a structural motif reminiscent of that found in 3 , with the hard quinolyl donor now occupying the position of the thf coordination site. In the ${ }^{1} \mathrm{H}$ NMR the proton of the $\mathrm{N} H$ functionality was clearly evidenced by a singlet at $4.76 \mathrm{ppm}$, while the presence of three singlets at $0.21,-0.25$, and $-0.35 \mathrm{ppm}$ for the metal bonded methyl groups and two doublets at 0.85 and $0.67 \mathrm{ppm}$ with a geminal coupling constant of ${ }^{2} J_{\mathrm{HH}}=14.5 \mathrm{~Hz}$ for the methylene group are consistent with the solid-state structure.

An X-ray diffraction study of 5 revealed that the lutetium metal center is coordinated by the $\mathrm{Cp}^{\mathrm{Q}}$ ligand via the $\eta^{5}-\mathrm{C}_{5} \mathrm{Me}_{4}$ moiety and the quinolyl nitrogen donor, one terminal and one bridging methyl group as well as the aluminium-linked amido ligand resulting in an overall coordination number of seven (see Fig. 4). The $\mathrm{Lu}-\mathrm{C}\left(\mathrm{CH}_{3}\right)$ and $\mathrm{Lu}-\mathrm{C}\left(\mu-\mathrm{CH}_{3}\right)$ bond lengths of

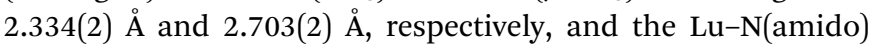
distance of 2.479(2) $\AA$ compare well to those detected in complex 3 considering the difference of the $\operatorname{Ln}(\mathrm{III})$ ionic radii. For comparison, complexes $\mathrm{Cp}^{*}{ }_{2} \mathrm{LuMe}{ }_{2} \mathrm{Li}(\mathrm{thf})_{3}{ }^{22 c}$ and $\left[\mathrm{Cp}^{*}{ }_{2} \mathrm{LuMe}\right]_{2}{ }^{31}$ show similar terminal $\mathrm{Lu}-\mathrm{C}\left(\mathrm{CH}_{3}\right)$ bond lengths of 2.361(9) $\AA$ and 2.423(3) $\AA$, respectively, whereas the bridging carbon bonds $\mathrm{Lu}-\mathrm{C}\left(\mu-\mathrm{CH}_{3}\right)$ can differ markedly ranging from $2.385(9)^{22 c}$ to 2.737(3) $\AA^{31}$ The bending of the nonlinear Lu1-N1-C32(ipso) fragment of $129.0(1)^{\circ}$ in $\mathbf{5}$ is much more pronounced than in the related complex $\left[\mathrm{Cp}^{*}{ }_{2} \mathrm{LuMe}(\mathrm{NHAr})\right]\left[\mathrm{Li}(12 \text {-crown-4) })_{2}\right](\mathrm{Ar}=$ $\left.\mathrm{C}_{6} \mathrm{H}_{3} i \mathrm{Pr}_{2}-2,6\right)\left(\mathrm{Lu}-\mathrm{N}=2.245(4) \AA\right.$ A, Lu-N-C = 155(3) $\left.{ }^{\circ}\right) .{ }^{22 c}$

Remarkably, the reaction of $\mathrm{Cp}^{\mathrm{Q}} \mathrm{Y}\left(\mathrm{AlMe}_{4}\right)_{2}$ with $\mathrm{H}_{2} \mathrm{Nmes}^{*}$ or $\mathrm{K}\left[\mathrm{NH}\left(\mathrm{mes}^{*}\right)\right]$ led to the formation of several metal-containing

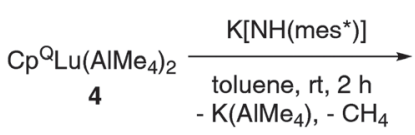
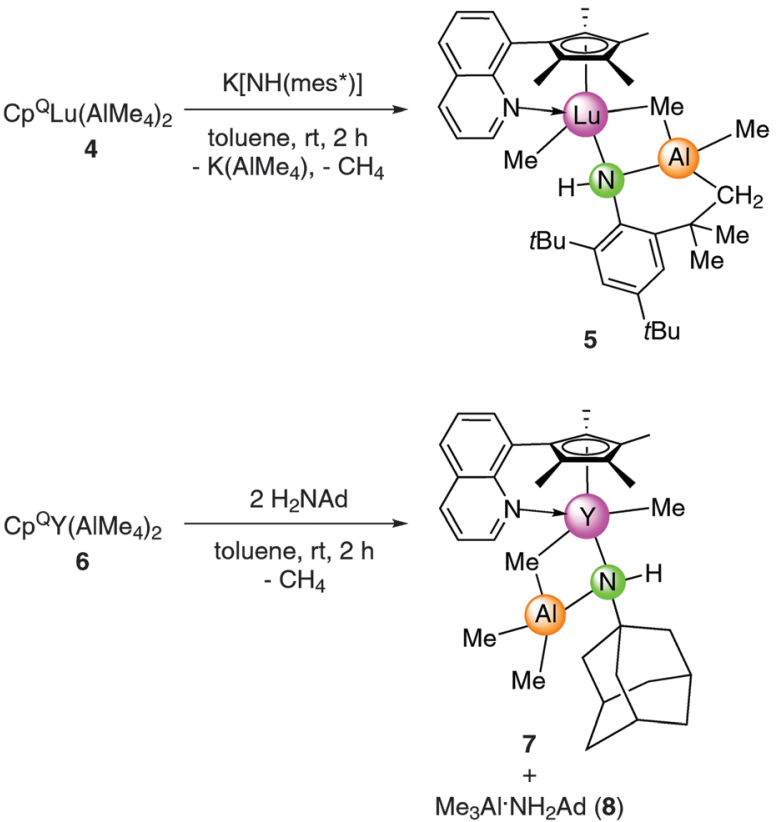

Scheme 3 Synthesis of anilide complexes $\mathbf{5}$ and $\mathbf{7}$.

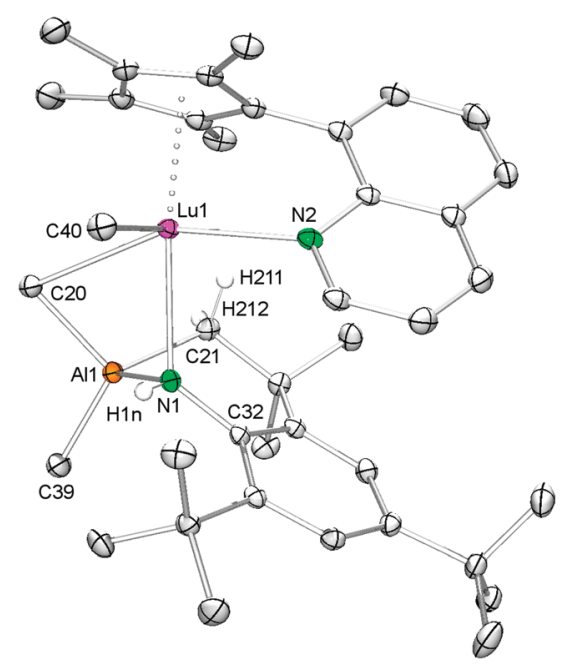

Fig. 4 Molecular structure of $\mathbf{5}$. Atoms are represented by atomic displacement ellipsoids set at the $30 \%$ level. Hydrogen atoms except for the $\mathrm{NH}$ proton and the methylene protons are omitted for clarity. Selected bond distances $[\AA ̊]$ and angles [deg]: Lu1-C20 2.703(2), Lu1-C40 2.334(2), Lu1-N1 2.479(2), Lu1-N2 2.401(2), Lu1…Ct1 2.339, Lu1...Al1 2.9694(6), Al1-N1 1.905(2), Al1-C20 2.023(2), Al1-C21 1.991(2), Al1-C39 1.964(2), Lu1-N1-C32 129.0(1), C20-Lu1-C40 89.45(8), C20-Lu1-N2 154.45(6), C20-Lu1-N1 71.84(5), C40-Lu1-N2 97.17(6), C40-Lu1-N1 86.91(6), N1-Lu1-Ct1 165.11, Lu1-C20-Al1-N1 41.27(7).

species. However, we have recently shown that protonolysis of complexes $\left(\mathrm{Tp}^{t \mathrm{Bu}, \mathrm{Me}}\right) \mathrm{YMe}\left(\mathrm{MMe}_{4}\right)(\mathrm{M}=\mathrm{Al}, \mathrm{Ga})$ with primary amines/anilines, is also a viable strategy to access imide species $\left(\mathrm{Tp}{ }^{t \mathrm{Bu}, \mathrm{Me}}\right) \mathrm{Ln}=\mathrm{NR}$ or $\left(\mathrm{Tp}^{t \mathrm{Bu}, \mathrm{Me}}\right) \mathrm{Ln}(\mathrm{NR})\left(\mathrm{AlMe}_{3}\right) \cdot{ }^{15,16}$ For assessing the feasibility of the protonolysis protocol for $\mathrm{Cp}$-based systems, we reacted $\mathrm{Cp}^{\mathrm{Q}} \mathrm{Y}\left(\mathrm{AlMe}_{4}\right)_{2}$ with 1-adamantylamine $\left(\mathrm{H}_{2} \mathrm{NAd}\right)$. Primary amine $\mathrm{H}_{2} \mathrm{NAd}$ was selected in order to minimize any $\mathrm{C}-\mathrm{H}$ bond activation at the ligand backbone. Accordingly, the reaction of 
6 with $\mathrm{H}_{2} \mathrm{NAd}$ afforded amide complex $\mathrm{Cp}^{\mathrm{Q}} \mathrm{YMe}[\mathrm{NH}(\mathrm{Ad})]\left(\mathrm{AlMe}_{3}\right)$ (7) together with adduct $\mathrm{Me}_{3} \mathrm{Al} \cdot \mathrm{NH}_{2}(\mathrm{Ad})$ (8) (Scheme 3). As anticipated $\mathrm{C}-\mathrm{H}$ bond activation of the amide ligand did not occur. The observed reactivity comes not as a total surprise since the reaction of $\operatorname{Ln}\left(\mathrm{AlMe}_{4}\right)_{3}(\mathrm{Ln}=\mathrm{Y}$, Lu) with 1-adamantylamine was previously shown to produce $\left[\mathrm{LnMe}_{3}\right]_{n}$ and $\mathrm{Me}_{3} \mathrm{Al} \cdot \mathrm{NH}_{2}(\mathrm{Ad})$. Such distinct reactivity clearly shows that the type of ancillary ligand (Cp versus $\mathrm{Tp}=$ tris(pyrazolyl)borate) affects organoaluminiumassisted deprotonation ${ }^{10,13}$ and Lewis base-induced aluminate cleavage $^{34}$ as competing reaction pathways and the action of primary amines as Brønsted acids or Lewis bases.

Anilide species 7 is sparingly soluble in aliphatic hydrocarbons but soluble in aromatic solvents. The ${ }^{1} \mathrm{H}$ NMR spectrum of 7 shows the expected set of signals for the coordinated $\mathrm{Cp}^{\mathrm{Q}}$ ligand. The four methyl groups of the Cp ring appear as two singlets at 1.78 and $2.20 \mathrm{ppm}$ and the signals of the quinolyl protons were found in the range from 6.57 to $8.88 \mathrm{ppm}$. All signals are shifted 0.1-0.3 ppm upfield compared to those of 6 , indicating the coordination of the adamantylamide ligand to the rare-earth metal center. The resonances assignable to the adamantyl methylene and methine groups were detected as a doublet at $2.28 \mathrm{ppm}(6 \mathrm{H})$, a multiplet ranging from 1.79 to $1.61 \mathrm{ppm}(6 \mathrm{H})$ and a broad singlet at $2.14 \mathrm{ppm}(3 \mathrm{H})$, respectively. Only one doublet was observed for the metal-bonded methyl groups in complex 7 at ambient temperature $(-0.06 \mathrm{ppm}, 12 \mathrm{H})$, which implies a high mobility of the $\mathrm{Y} / \mathrm{Al}-\mathrm{CH}_{3}$ moieties. Such a facile exchange of a terminal $\mathrm{Y}-\mathrm{CH}_{3}$ and a bridging methyl group $\mathrm{Y}-\mathrm{CH}_{3}-\mathrm{M}$ has been observed before in $\left(\mathrm{Tp}^{t \mathrm{Bu}, \mathrm{Me}}\right) \mathrm{YMe}\left[(\mu-\mathrm{Me})\left(\mathrm{GaMe}_{3}\right)\right]{ }^{16}$ The open coordination sphere at the yttrium metal center seems to enable enhanced methyl group mobility.

Single crystals of 7 suitable for X-ray structure analysis were grown from toluene- $n$-hexane mixtures at $-35{ }^{\circ} \mathrm{C}$. In the solid state, complex 7 is heptacoordinate by one terminal and one bridging methyl group, the amido nitrogen atom as well as the $\mathrm{Cp}^{\mathrm{Q}}$ ligand binding via the $\mathrm{Cp}$ ring $\left(\eta^{5}\right)$ and the nitrogen atom of the quinolyl moiety (see Fig. 5). The amido ligand and the

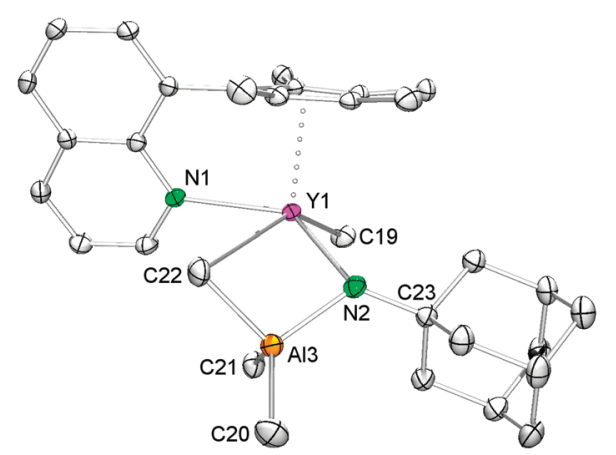

Fig. 5 Molecular structure of 7. Atoms are represented by atomic displacement ellipsoids set at the $50 \%$ level. Selected bond distances $[\AA]]$ and angles [deg]: Y1-C19 2.392(2), Y1 ...C22 3.006(2), Y1-N1 2.527(2), Y1-N2 2.428(2), Y1‥Ct1 2.366, Y1A Al3 3.0417(6), Al3-C20 1.964(2), Al3-C21 2.007(2), Al3-C22 2.022(2), Al3-N2 1.920(2), Y1-N2-C23 126.9(1), $\mathrm{Y} 1-\mathrm{N} 2-\mathrm{Al} 3$ 87.98(7), C19-Y1-C22 144.61(7), N1-Y1-N2 140.16(6), C19-Y1-N2 103.26(7), C19-Y1-N1 95.24(7), C22-Y1-N1 78.49(6), Y1-N2-Al3-C22 -55.70(9).
$(\mu-\mathrm{Me}) \mathrm{AlMe}_{2}$ moiety form a heterobimetallic four-membered ring, which is considerably bent (torsion angle $\mathrm{Y} 1-\mathrm{N} 2-\mathrm{Al} 3-\mathrm{C} 22$ $\left.-55.70(9)^{\circ}\right)$, resulting in a smaller Y . A Al separation of 3.0417(6) than in precursor 6 (av. 3.1784(7) $\AA^{3} .{ }^{33}$ The mean metal-ringcarbon distances $\mathrm{Ln}-\mathrm{C}\left(\mathrm{Cp}^{\mathrm{Q}}\right)$ (av. 2.656(2) $\mathrm{A}$ ) and the $\mathrm{Y}-\mathrm{N}($ quinolyl) bond length $(2.527(2) \AA)$ are similar to those found in 6 . $^{33}$ The bond length of the terminal methyl group $\mathrm{Y}-\mathrm{C}\left(\mathrm{CH}_{3}\right)(2.392(2) \AA)$ compares well to that found in 3 while the distance of the bridging $\mathrm{Y}-\mathrm{C}\left(\mu-\mathrm{CH}_{3}\right)$ moiety $(3.006(2) \AA)$ is significantly longer than the one found in $3(\mathrm{Y} 1-\mathrm{C} 1=2.827(3) \AA)$ and markedly longer than the average distances $\mathrm{Y}-\mathrm{C}\left(\mathrm{CH}_{3}\right)(2.645(2) \AA)$ in homoaluminate precursor $6^{33}$ The $\mathrm{Y}-\mathrm{N}$ (amido) bond length of 2.428(2) A is slightly shorter than in 3, reflecting a less sterically crowded coordination environment around the metal center.

In Scheme 4, we propose a plausible mechanistic scenario for the formation of half-sandwich amide complexes 3, 5, and 7: both salt metathesis involving $\mathrm{Cp}^{\mathrm{R}} \mathrm{Ln}\left(\mathrm{AlMe}_{4}\right)_{2}$ and $\mathrm{KNHR}$ (Scheme 4a) and protonolysis involving $\mathrm{Cp}^{\mathrm{R}} \mathrm{Ln}\left(\mathrm{AlMe}_{4}\right)_{2}$ and $\mathrm{H}_{2} \mathrm{NR}$ (Scheme 4b) afford intermediate $\mathbf{I}^{\mathbf{2}}$, which in the absence of donor functionalities can be isolated as shown for $\mathbf{2 a}$ and $\mathbf{2 b}$. The protonolysis reaction is preceded by an amine-induced tetramethylaluminate cleavage and the formation of a transient terminal $\mathrm{Ln}-\mathrm{CH}_{3}$ moiety $\left(\mathbf{I}^{\mathbf{1}}\right)$, which reacts instantly with another amine molecule via methane elimination to generate $\mathbf{I}^{2}$. The occurrence of donorinduced tetramethylaluminate cleavage as the rate-determining step along reaction path $\mathbf{b}$ is supported by the formation of considerable amounts of 7 along with $\mathrm{AlMe}_{3}\left(\mathrm{H}_{2} \mathrm{NR}\right)(8)$ in equimolar reactions of 6 and $\mathrm{H}_{2}$ NAd. Intermediate $\mathbf{I}^{2}$ is not stable in the presence of donor functionalities (quinolyl or thf), which can exert enhanced steric pressure on the amido as well as tetramethylaluminato ligands. As a consequence the amido

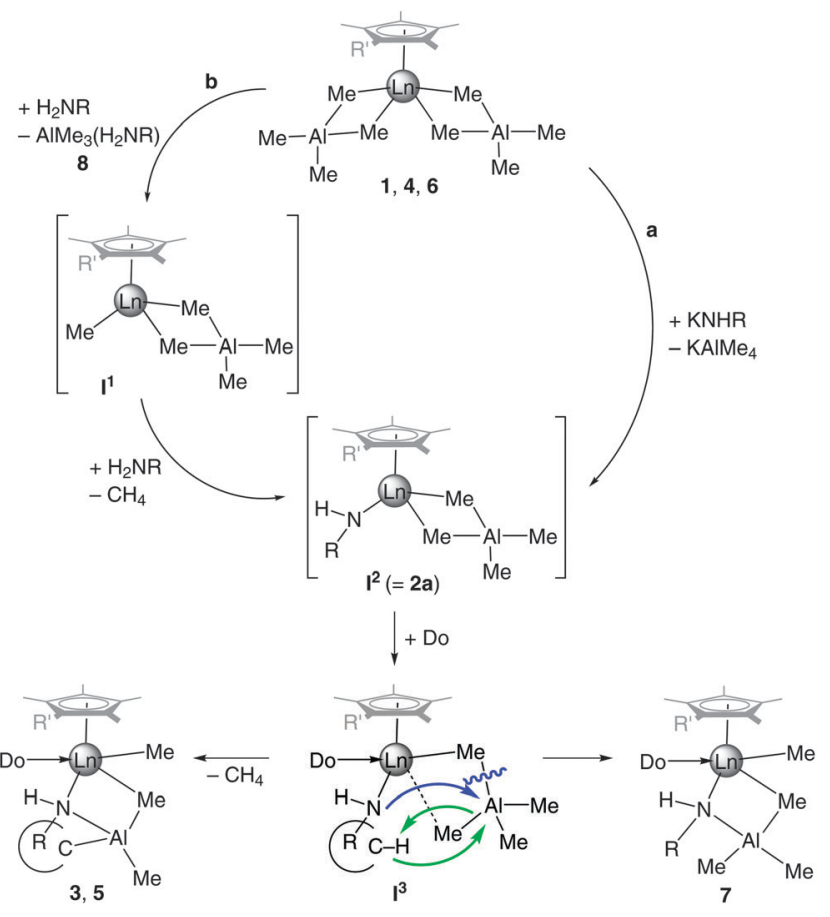

Scheme 4 Proposed reaction mechanism for the formation of $\mathbf{3}, \mathbf{5}$, and $\mathbf{7}$. 


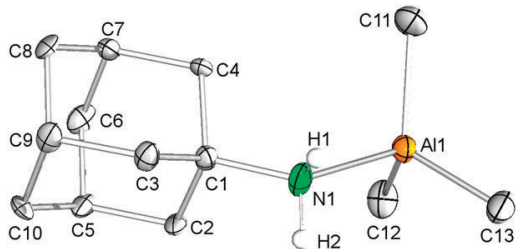

Fig. 6 Molecular structure of $\mathbf{8}$. Atoms are represented by atomic displacement ellipsoids set at the $50 \%$ level. The disorders in the adamantyl moiety and hydrogen atoms except for the $\mathrm{NH}_{2}$ protons are omitted for clarity. Selected bond distances $[\AA \AA]$ and angles [deg]: Al1-C11 1.988(2), Al1-C12 1.976(2), Al1-C13 1.986(2), Al1-N1 2.032(1), Al1-N1-C1 126.41(9), C12-Al1-C13 113.32(9), C12-Al1-C11 116.32(8), C13-Al1-C11 113.38(9), C12-Al1-N1 107.25(8), C13-Al1-N1 99.39(6), C11-Al1-N1 105.13(8).

nitrogen can approach the aluminate ligand (blue arrow), which might experience a $\eta^{2}-\eta^{1}$ coordination switch, ultimately leading to an aluminate cleavage and concomitantly to the formation of a stable $\mathrm{Al}-\mathrm{N}$ bond as well as a (second) $\mathrm{Ln}-\mathrm{CH}_{3}$ moiety (isolation of complex 7). In the case of proximal alkyl moieties, the organoaluminium fragment can trigger $\mathrm{C}-\mathrm{H}$ bond activation (green arrows), as evidenced for the formation of complexes $\mathbf{3}$ and $\mathbf{5 .}$

\section{Synthesis and characterization of $\mathrm{Me}_{3} \mathrm{Al} \cdot \mathrm{NH}_{2}$ (Ad) (8)}

Byproduct 8, which could be separated from 7 by extraction with $n$-hexane, was independently synthesized in quantitative yield via the addition of $\mathrm{AlMe}_{3}$ to a toluene solution of 1-adamantylamine. Recrystallization from toluene- $n$-hexane at $-35{ }^{\circ} \mathrm{C}$ gave colourless crystals. In the solid-state, the aluminium center adopts a distorted tetrahedral coordination geometry (Fig. 6). The average $\mathrm{Al}-\mathrm{C}\left(\mathrm{CH}_{3}\right)$ bond length of $1.983 \AA$ and the Al-N(amine) distance of 2.032(1) $\AA$ are in accord with the corresponding metrical parameters observed for the related complex $\mathrm{Me}_{3} \mathrm{Al} \cdot \mathrm{NH}_{2}(t \mathrm{Bu})^{35}$ (av. $\mathrm{Al}-\mathrm{C}=1.96 \AA, \mathrm{Al}-\mathrm{N}=2.027(3) \AA$ ) and 7 (av. Al-C = 1.998 $\mathrm{A}$ ), but are considerably elongated compared to the Al-N(amido) bond length in $7(\mathrm{Al}-\mathrm{N}=1.920(2) \AA)$. As expected, the ${ }^{1} \mathrm{H}$ NMR spectrum of aluminium complex 8 in $\mathrm{C}_{6} \mathrm{D}_{6}$ shows one highfield signal for the methyl groups at $-0.36 \mathrm{ppm}(9 \mathrm{H})$, a singlet for the $\mathrm{NH}_{2}$ functionality at $1.59 \mathrm{ppm}(2 \mathrm{H})$, a broad singlet for the methine groups $(3 \mathrm{H})$, a doublet at $1.20 \mathrm{ppm}$ and a multiplett at $1.27 \mathrm{ppm}$ for the methylene groups integrating six protons each, respectively.

\section{Conclusion}

The reactions of monocyclopentadienyl rare-earth metal bis(tetramethylaluminate) complexes with 1-adamantylamine or potassium (2,4,6-tri-tert-butylphenyl)amide yield half-sandwich mixed alkyl-amide complexes. The reactivity of the metal-bonded alkyl groups toward adjacent $\mathrm{NH}$ functionalities appears strongly reduced and further deprotonation was not observed. This is in sharp contrast to previously examined complexes $\left(\mathrm{Tp}^{t \mathrm{Bu}, \mathrm{Me}}\right)$ $\mathrm{YMe}\left(\mathrm{AlMe}_{4}\right)$, which do react with primary amines/anilines to afford Lewis-acid stabilized imido derivatives $\left(\mathrm{Tp}^{t \mathrm{Bu}, \mathrm{Me}}\right) \mathrm{Ln}(\mathrm{NR})$ $\left(\mathrm{AlMe}_{3}\right){ }^{15}$ Such changed reactivity of complexes $\mathrm{Cp}^{*} \operatorname{Ln}\left(\mathrm{AlMe}_{4}\right)_{2}$ and $\mathrm{Cp}^{\mathrm{Q}} \mathrm{Ln}\left(\mathrm{AlMe}_{4}\right)_{2}$ might be caused by a steric misfit of the metal-alkyl and $\mathrm{N}-\mathrm{H}$ groups, since the former still exhibit high reactivity as shown for the $\mathrm{C}-\mathrm{H}$ activation of the $\mathrm{NH}\left(\right.$ mes $\left.^{*}\right)$ amido ligand backbone. Though substitution of mes* by adamantyl decreases the reactivity of the $\mathrm{NH}$ moiety ( $\mathrm{p} K_{\mathrm{a}}$ criterion), the occurrence of undesired side-reactions is impeded. Previous studies from the Hessen and Hou groups revealed that imides could only be obtained from reactive $\mathrm{Cp}$ ligated rare-earth metal hydride and diene complexes via the insertion of benzonitrile. ${ }^{2 b, 36}$ Overall, the present study reinforces that primary alkylamines not only act as protic substrates but also as Lewis bases and that the steric and electronic properties of the ancillary ligands are crucial factors directing the formation of either heteroleptic alkyl-amide complexes or imide species. ${ }^{15}$

\section{Experimental section}

\section{General considerations}

All operations were performed with rigorous exclusion of air and water, using standard Schlenk, high-vacuum, and glovebox techniques (MBraun 200B; $<1$ ppm $\mathrm{O}_{2},<1$ ppm $\mathrm{H}_{2} \mathrm{O}$ ). THF, toluene and $n$-hexane were purified by using Grubbs columns (MBraun SPS, solvent purification system) and stored inside a glovebox. $\mathrm{C}_{6} \mathrm{D}_{6}$ and toluene- $d_{8}$ were obtained from Aldrich, degassed, dried over $\mathrm{Na}$ for $24 \mathrm{~h}$, and filtered. 1-Adamantylamine was received from abcr and used as received. Pro-ligand $\mathrm{HCp}^{\mathrm{Q}}, 37$ heteroleptic complexes $C \mathrm{p}^{*} \operatorname{Ln}\left(\mathrm{AlMe}_{4}\right)_{2}(\mathrm{Ln}=\mathrm{Y}, \mathrm{La})(\mathbf{1})^{8}$ and $\mathrm{Cp}^{\mathrm{Q}} \mathrm{Y}\left(\mathrm{AlMe}_{4}\right)_{2}(\mathbf{6}),{ }^{33}$ and potassium (2,4,6-Tri-tert-butylphenyl)amide $^{13}$ were synthesized according to literature procedures. The NMR spectra of air and moisture sensitive compounds were recorded by using J. Young valve NMR tubes at variable temperature on a Bruker AVII+400 ( $\left.{ }^{1} \mathrm{H}: 400 \mathrm{MHz} ;{ }^{13} \mathrm{C}: 101 \mathrm{MHz}\right)$ and a Bruker AVII+500 $\left({ }^{1} \mathrm{H}: 500 \mathrm{MHz} ;{ }^{13} \mathrm{C}: 126 \mathrm{MHz}\right) \cdot{ }^{1} \mathrm{H}$ and ${ }^{13} \mathrm{C}$ shifts are referenced to internal solvent resonances and reported in parts per million relative to TMS. Coupling constants are given in Hertz. DRIFT spectra were recorded on a NICOLET 6700 FTIR spectrometer using dried $\mathrm{KBr}$ and $\mathrm{KBr}$ windows. Elemental analyses were performed on an Elementar Vario Micro Cube.

\section{General procedures for the synthesis of $\left\{\mathrm{Cp}^{*} \operatorname{Ln}\left(\mathrm{AlMe}_{4}\right)\left[\mathrm{NH}\left(\mathrm{mes}^{*}\right)\right]\right\}_{x}$}

A solution of $\left(\mathrm{Cp}^{*}\right) \operatorname{Ln}\left(\mathrm{AlMe}_{4}\right)_{2}$ in $n$-hexane $(2 \mathrm{~mL})$ was added to a stirred suspension of potassium (2,4,6-tri-tert-butylphenyl)amide $\mathrm{K}\left[\mathrm{NH}\left(\mathrm{mes}^{*}\right)\right]$ in $n$-hexane $(2 \mathrm{~mL})$. The reaction mixture was stirred for $2 \mathrm{~h}$ at ambient temperature and the $n$-hexane solution then separated by centrifugation, decanted, and filtrated. The solid residue product and $\mathrm{K}\left(\mathrm{AlMe}_{4}\right)$ were extracted with additional $n$-hexane $(2 \times 2 \mathrm{ml})$. Compounds 2 were obtained as powders or by crystallization from $n$-hexane solutions at $-35{ }^{\circ} \mathrm{C}$.

$\left\{\mathbf{C p}^{*} \mathbf{Y}\left(\mathrm{AlMe}_{\mathbf{4}}\right)\left[\mathbf{N H}\left(\mathbf{m e s}^{*}\right)\right]\right\}_{2}$ (2a). Following the procedure described above, $\left(\mathrm{Cp}^{*}\right) \mathrm{Y}\left(\mathrm{AlMe}_{4}\right)_{2}(80 \mathrm{mg}, 0.20 \mathrm{mmol})$ and $\mathrm{K}\left[\mathrm{NH}\left(\mathrm{mes}^{*}\right)\right](60 \mathrm{mg}, 0.20 \mathrm{mmol})$ yielded $2 \mathrm{a}$ as colourless crystals (121 mg, $0.20 \mathrm{mmol}$, quant., 83\% crystalline yield). ${ }^{1} \mathrm{H}$ NMR (500 MHz, $\left.\mathrm{C}_{6} \mathrm{D}_{6}, 26{ }^{\circ} \mathrm{C}, \mathrm{TMS}\right): \delta=7.38\left(\mathrm{~s}, 4 \mathrm{H}, H_{\text {aryl }}\right), 5.05(\mathrm{~s}, 2 \mathrm{H}$, $\mathrm{NH}), 1.89\left(\mathrm{~s}, 30 \mathrm{H}, \mathrm{CH}_{3}, \mathrm{Cp}^{*}\right), 1.44\left(\mathrm{~s}, 18 \mathrm{H},\left(\mathrm{C}\left(\mathrm{CH}_{3}\right)_{3}\right)_{\text {para }}\right), 1.41$ $\left(\mathrm{s}, 36 \mathrm{H},\left(\mathrm{C}\left(\mathrm{CH}_{3}\right)_{3}\right)_{\text {ortho }}\right),-0.33\left(\mathrm{~d}, 24 \mathrm{H},{ }^{2} J_{\mathrm{YH}}=2.5 \mathrm{~Hz}, \mathrm{Al}\left(\mathrm{CH}_{3}\right)_{4}\right)$. ${ }^{13} \mathrm{C}$ NMR (126 MHz, $\left.\mathrm{C}_{6} \mathrm{D}_{6}, 26{ }^{\circ} \mathrm{C}\right) \delta=151.3$ (Ar, $\left.C_{i p s o}\right)$, 
$138.0\left(\mathrm{Ar}, C_{\text {para }}\right), 133.0\left(\mathrm{Ar}, C_{\text {ortho }}\right), 123.4\left(\mathrm{Ar}, C_{\text {meta }}\right), 121.2$ $\left(C_{5}\left(\mathrm{CH}_{3}\right)_{5}\right), \quad 35.8 \quad\left(\left(\mathrm{C}\left(\mathrm{CH}_{3}\right)_{3}\right)_{\text {ortho }}\right), \quad 34.9 \quad\left(\left(\mathrm{C}\left(\mathrm{CH}_{3}\right)_{3}\right)_{\text {para }}\right), \quad 32.4$ $\begin{array}{llllll}\left(\left(\mathrm{C}\left(\mathrm{CH}_{3}\right)_{3}\right)_{\text {para }}\right), & 31.3 & \left(\left(\mathrm{C}\left(\mathrm{CH}_{3}\right)_{3}\right)_{\text {ortho }}\right), & 12.0 & \left(\mathrm{C}_{5}\left(\mathrm{CH}_{3}\right)_{5}\right), & 1.1\end{array}$ $\left(\mathrm{Al}\left(\mathrm{CH}_{3}\right)_{4}\right)$ ppm. DRIFT (KBr): 3416vw (NH), 2959vs, 2912s, 2871s, 1594vw, 1476w, 1456m, 1419s, 1393m, 1361m, 1280w, $1240 \mathrm{~s}, 1195 \mathrm{~m}, 1119 \mathrm{w}, 1024 \mathrm{w}, 931 \mathrm{w}, 912 \mathrm{w}, 879 \mathrm{~m}, 835 \mathrm{~m}, 778 \mathrm{~m}$, $745 \mathrm{~m}, 719 \mathrm{~m}, 677 \mathrm{~m}, 624 \mathrm{~m}, 565 \mathrm{~m}, 545 \mathrm{~m}, 480 \mathrm{w}, 449 \mathrm{w} \mathrm{cm} \mathrm{cm}^{-1}$. Elemental analysis calcd (\%) for $\mathrm{C}_{32} \mathrm{H}_{57} \mathrm{AlNY}\left(571.69 \mathrm{~g} \mathrm{~mol}^{-1}\right)$ : C 67.23, H 10.05, N 2.45; found: C 67.26, H 10.13, N 2.32.

$\left\{\mathbf{C p}^{*} \mathbf{L a}\left(\mathrm{AlMe}_{4}\right)\left[\mathbf{N H}\left(\mathrm{mes}^{*}\right)\right]\right\}_{\boldsymbol{x}}$ (2b). Following the procedure described above, $\left(\mathrm{Cp}^{*}\right) \mathrm{La}\left(\mathrm{AlMe}_{4}\right)_{2}(90 \mathrm{mg}, 0.20 \mathrm{mmol})$ and $\mathrm{K}\left[\mathrm{NH}\left(\mathrm{mes}^{*}\right)\right](60 \mathrm{mg}, 0.20 \mathrm{mmol}$ ) yielded $2 \mathbf{b}$ as a light yellow powder (108 mg, $0.17 \mathrm{mmol}, 87 \%) .{ }^{1} \mathrm{H}$ NMR (500 MHz, $\mathrm{C}_{6} \mathrm{D}_{6}$, $\left.26{ }^{\circ} \mathrm{C}, \mathrm{TMS}\right): \delta=7.38\left(\mathrm{~s}, 2 \mathrm{H}, H_{\text {aryl }}\right), 5.83(\mathrm{~s}, 1 \mathrm{H}, \mathrm{NH}), 2.04(\mathrm{~s}, 15 \mathrm{H}$, $\left.\mathrm{CH}_{3}, \mathrm{Cp}^{*}\right), 1.42\left(\mathrm{~s}, 9 \mathrm{H},\left(\mathrm{C}\left(\mathrm{CH}_{3}\right)_{3}\right)_{\text {para }}\right), 1.33\left(\mathrm{~s}, 18 \mathrm{H},\left(\mathrm{C}\left(\mathrm{CH}_{3}\right)_{3}\right)_{\text {ortho }}\right)$, $-0.43\left(\mathrm{~s} \mathrm{br}, 12 \mathrm{H}, \mathrm{Al}\left(\mathrm{CH}_{3}\right)_{4}\right) \cdot{ }^{13} \mathrm{C} \mathrm{NMR}\left(126 \mathrm{MHz}, \mathrm{C}_{6} \mathrm{D}_{6}, 26{ }^{\circ} \mathrm{C}\right) \delta=$ $150.2\left(\mathrm{Ar}, C_{\text {ipso }}\right), 139.9\left(\mathrm{Ar}, C_{\text {para }}\right), 134.6\left(\mathrm{Ar}, C_{\text {ortho }}\right), 125.3(\mathrm{Ar}$, $\left.C_{\text {meta }}\right), 123.4\left(\mathrm{C}_{5}\left(\mathrm{CH}_{3}\right)_{5}\right), 36.5\left(\left(C\left(\mathrm{CH}_{3}\right)_{3}\right)_{\text {ortho }}\right), 35.0\left(\left(C\left(\mathrm{CH}_{3}\right)_{3}\right)_{\text {para }}\right)$, $32.3\left(\left(\mathrm{C}\left(\mathrm{CH}_{3}\right)_{3}\right)_{\text {para }}\right), 31.4\left(\left(\mathrm{C}\left(\mathrm{CH}_{3}\right)_{3}\right)_{\text {ortho }}\right), 11.8\left(\mathrm{C}_{5}\left(\mathrm{CH}_{3}\right)_{5}\right), 2.6$ $\left(\mathrm{Al}\left(\mathrm{CH}_{3}\right)_{4}\right)$ ppm. DRIFT (KBr): 3405vw (NH), 2963vs, 2909vs, 2870s, 2835m, 1597vw, 1498vw, 1477w, 1464w, 1416s, 1393m, $1383 \mathrm{~m}, 1362 \mathrm{~m}, 1279 \mathrm{~m}, 1251 \mathrm{~m}, 1241 \mathrm{~m}, 1220 \mathrm{w}, 1202 \mathrm{w}, 1175 \mathrm{~m}$, $1114 \mathrm{w}, 1023 \mathrm{vw}, 986 \mathrm{~m}, 960 \mathrm{~s}, 883 \mathrm{vw}, 825 \mathrm{w}, 809 \mathrm{w}, 783 \mathrm{w}, 768 \mathrm{w}$, $727 \mathrm{~s}, 674 \mathrm{w}, 641 \mathrm{vw}, 610 \mathrm{~s}, 555 \mathrm{~s}, 539 \mathrm{~s}, 501 \mathrm{vw}, 478 \mathrm{vw}, 419 \mathrm{w} \mathrm{cm} \mathrm{cm}^{-1}$. Elemental analysis calcd (\%) for $\mathrm{C}_{32} \mathrm{H}_{57} \mathrm{AlLaN}\left(621.69 \mathrm{~g} \mathrm{~mol}^{-1}\right.$ ): C 61.82, H 9.24, N 2.25; found: C 61.58, H 9.60, N 1.98.

$\mathrm{Cp}^{*} \mathrm{YMe}\left\{\mathrm{NH}\left[\mathrm{C}_{6} \mathrm{H}_{2} t \mathrm{Bu}_{2}-2,4-\left(\mathrm{CMe}_{2} \mathrm{CH}_{2}\right)-6\right]\right\}\left(\mathrm{AlMe}_{2}\right)($ thf $)$

Tetrahydrofuran $(1 \mathrm{ml})$ was added to solid $2 \mathrm{a}(57 \mathrm{mg}, 0.10 \mathrm{mmol})$ at ambient temperature. The obtained yellow solution was dried in vacuo and recrystallized in $n$-hexane at $-35{ }^{\circ} \mathrm{C}$ (estimated yield $29 \mathrm{mg}, 46 \%$ ). Single crystals of 3 suitable for X-ray diffraction were harvested from saturated $n$-hexane solutions at $-35{ }^{\circ} \mathrm{C} .{ }^{1} \mathrm{H}$ NMR measurements were hampered by rapid decomposition of 3 . DRIFT (KBr): 3402vw (NH), 2958vs, 2927s, 2907s, 2887s, 2741w, $1457 \mathrm{~m}, 1423 \mathrm{~s}, 1394 \mathrm{w}, 1361 \mathrm{~m}, 1335 \mathrm{w}, 1286 \mathrm{w}, 1228 \mathrm{~s}, 1189 \mathrm{w}$, $1157 \mathrm{w}, 1120 \mathrm{~m}, 1103 \mathrm{w}, 1014 \mathrm{~m}, 921 \mathrm{ww}, 878 \mathrm{w}, 863 \mathrm{w}, 830 \mathrm{w}, 814 \mathrm{w}$, $778 \mathrm{w}, 752 \mathrm{~s}, 736 \mathrm{~m}, 695 \mathrm{~s}, 627 \mathrm{w}, 559 \mathrm{w}, 520 \mathrm{vw}, 473 \mathrm{w} \mathrm{cm}^{-1}$. Elemental analysis calcd (\%) for $\mathrm{C}_{35} \mathrm{H}_{61} \mathrm{AlNOY}\left(627.75 \mathrm{~g} \mathrm{~mol}^{-1}\right.$ ): $\mathrm{C} 66.97, \mathrm{H}$ 9.79, N 2.23; found: C 67.37, H 10.24, N 2.01.

$\mathrm{Cp}^{\mathrm{Q}} \mathbf{L u}\left(\mathrm{AlMe}_{4}\right)_{2}$ (4). A solution of $\mathrm{Lu}\left(\mathrm{AlMe}_{4}\right)_{3}(87 \mathrm{mg}, 0.20 \mathrm{mmol})$ in $n$-hexane $(3 \mathrm{~mL})$ was added to a stirred suspension of $\mathrm{HCp}^{\mathrm{Q}}$ (50 mg, $0.20 \mathrm{mmol}$ ) in $n$-hexane $(1 \mathrm{~mL})$. Instant gas formation was observed and the solution turned yellow with a thick, brown slurry at the bottom. The reaction mixture was stirred another $3 \mathrm{~h}$ at ambient temperature and then dried under vacuum. To the residue toluene $(2 \mathrm{~mL})$ was added and the brown solution was stirred for another $3 \mathrm{~h}$ at ambient temperature. The product was dried in vacuo and washed with $n$-hexane $(5 \times 2 \mathrm{~mL})$. The obtained brown solid was dried under reduced pressure (113 mg, 95\%). Crystals of 4 were obtained from a saturated, yellow toluene$n$-hexane solution at $-35{ }^{\circ} \mathrm{C} .{ }^{1} \mathrm{H}$ NMR $\left(500 \mathrm{MHz}, \mathrm{C}_{6} \mathrm{D}_{6}, 26{ }^{\circ} \mathrm{C}\right.$, TMS): $\delta=8.31\left(\mathrm{~d}, 1 \mathrm{H},{ }^{3} J_{\mathrm{HH}}=4.0 \mathrm{~Hz}\right.$, quin- $\left.H\right), 7.32\left(\mathrm{~d}, 1 \mathrm{H},{ }^{3} J_{\mathrm{HH}}=\right.$ $8.0 \mathrm{~Hz}$, quin- $H$ ), $7.29\left(\mathrm{dd}, 1 \mathrm{H},{ }^{3} J_{\mathrm{HH}}=3.9 \mathrm{~Hz}\right.$ and $\left.2.3 \mathrm{~Hz}\right), 7.12-$ $7.08(\mathrm{~m}, 2 \mathrm{H}$, quin- $H), 6.53(\mathrm{~m}, 1 \mathrm{H}$, quin- $H), 2.02(\mathrm{~s}, 6 \mathrm{H}$, $\mathrm{Cp}, \mathrm{CH}_{3}$ ), 1.78 (s, 6H, Cp, $\mathrm{CH}_{3}$ ), -0.13 (s, 24H, Al- $\mathrm{CH}_{3}$ ) ppm. ${ }^{13} \mathrm{C}\left\{{ }^{1} \mathrm{H}\right\}$ NMR (126 MHz, $\left.\mathrm{C}_{6} \mathrm{D}_{6}, 26{ }^{\circ} \mathrm{C}\right) \delta=151.3$ (quin- $C$ ),
150.7 (quin- $C$ ), 140.2 (quin- $C$ ), 135.4 (quin- $C$ ), 134.0 (quin- $C$ ), 129.8 (quin- $C$ ), 127.4 (quin- $C$ ), 123.0 (quin- $C$ ), 121.9 (quin- $C$ and Cp), 121.3 (Cp), 120.0 (Cp), $12.3\left(\mathrm{Cp} \mathrm{CH}_{3}\right), 11.5$ ( $\left.\mathrm{Cp} \mathrm{CH}_{3}\right), 2.2$ $\left(\mathrm{Al}-\mathrm{CH}_{3}\right)$ ppm. DRIFT (KBr): 2915s, 2886m, 2816w, 1593w, $1510 \mathrm{~m}, 1435 \mathrm{w}, 1371 \mathrm{w}, 1302 \mathrm{w}, 1220 \mathrm{w}, 1190 \mathrm{~m}, 1025 \mathrm{ww}, 970 \mathrm{vw}$, 844w, 824w, 790m, 764w, 706vs, 578m, 519w, 478w cm $\mathrm{cm}^{-1}$. Elemental analysis calcd (\%) for $\mathrm{C}_{26} \mathrm{H}_{42} \mathrm{Al}_{2} \mathrm{LuN}\left(597.55 \mathrm{~g} \mathrm{~mol}^{-1}\right.$ ): $\mathrm{C} 52.26, \mathrm{H}$ 7.08, N 2.34; found: C 53.43, H 7.36, N 2.54. Multiple attempts to obtain a better microanalysis failed.

\section{$\mathrm{Cp}^{\mathrm{Q}} \mathrm{LuMe}\left\{\mathrm{NH}\left[\mathrm{C}_{6} \mathrm{H}_{2} t \mathrm{Bu}_{2}-2,4-\left(\mathrm{CMe}_{2} \mathrm{CH}_{2}\right)-6\right]\right\}\left(\mathrm{AlMe}_{2}\right)$ (5)}

To a stirred suspension of $\mathrm{K}\left[\mathrm{NH}\left(\mathrm{mes}^{*}\right)\right]$ in toluene $(1 \mathrm{~mL})$ a solution of 4 ( $87 \mathrm{mg}, 0.14 \mathrm{mmol})$ in toluene $(3 \mathrm{~mL})$ was added. The brown suspension was stirred $3 \mathrm{~h}$ at ambient temperature and the product then separated by centrifugation, decanted, and filtrated. The solid residue product and $\mathrm{K}\left(\mathrm{AlMe}_{4}\right)$ was extracted with additional toluene $(2 \times 1 \mathrm{ml})$. The combined extracts were dried and washed with $n$-hexane $(3 \times 2 \mathrm{ml})$, followed by drying under reduced pressure ( $96 \mathrm{mg}, 0.12 \mathrm{mmol}, 91 \%, 30 \%$ crystalline yield). Crystallization from a toluene- $n$-hexane solution at $-35{ }^{\circ} \mathrm{C}$ afforded yellow crystals of 5 suitable for X-ray diffraction analysis. ${ }^{1} \mathrm{H}$ NMR (500 MHz, $\left.\mathrm{C}_{6} \mathrm{D}_{6}, 26{ }^{\circ} \mathrm{C}, \mathrm{TMS}\right): \delta=8.03\left(\mathrm{~d}, 1 \mathrm{H},{ }^{3} J_{\mathrm{HH}}=\right.$ $4.0 \mathrm{~Hz}$, quin- $H$ ), $7.67\left(\mathrm{~d}, 1 \mathrm{H},{ }^{3} J_{\mathrm{HH}}=2.3 \mathrm{~Hz}\right.$, quin- $\left.H\right), 7.45-7.43(\mathrm{~m}$, $3 \mathrm{H}$, quin- $H$ ), $7.30\left(\mathrm{~d}, 1 \mathrm{H},{ }^{3} J_{\mathrm{HH}}=8.5 \mathrm{~Hz}\right.$, quin- $\left.H\right), 7.20(\mathrm{~s}, 1 \mathrm{H}, \mathrm{Ar})$, 7.13-7.00 (m, 2H, quin- $H$ and $\mathrm{Ar}), 6.41\left(\mathrm{dd}, 1 \mathrm{H},{ }^{3} J_{\mathrm{HH}}=8.1 \mathrm{~Hz}\right.$ and $3.2 \mathrm{~Hz}$ ), $4.76(\mathrm{~s}, 1 \mathrm{H}, \mathrm{NH}), 2.28$ (s, 3H, Cp $\left.\mathrm{CH}_{3}\right), 2.06$ (s, 3H, Cp $\left.\mathrm{CH}_{3}\right), 2.04\left(\mathrm{~s}, 3 \mathrm{H}, \mathrm{Cp} \mathrm{CH}_{3}\right), 1.84$ (s, 3H, Cp $\left.\mathrm{CH}_{3}\right), 1.53$ (s, 9H, $\left.\mathrm{C}\left(\mathrm{CH}_{3}\right)_{3}\right), 1.49\left(\mathrm{~s}, 6 \mathrm{H}, \mathrm{C}\left(\mathrm{CH}_{3}\right)_{2}\right), 1.36\left(\mathrm{~s}, 9 \mathrm{H}, \mathrm{C}\left(\mathrm{CH}_{3}\right)_{3}\right), 0.85(\mathrm{~d}, 1 \mathrm{H}$, $\left.{ }^{2} J_{\mathrm{HH}}=14.5 \mathrm{~Hz}, \mathrm{Al}-\mathrm{CH}_{2}\right), 0.67\left(\mathrm{~d}, 1 \mathrm{H},{ }^{2} J_{\mathrm{HH}}=14.5 \mathrm{~Hz}, \mathrm{Al}-\mathrm{CH}_{2}\right), 0.21$ $\left(\mathrm{s}, 3 \mathrm{H}, \mathrm{Lu}-\mathrm{CH}_{3}\right),-0.25\left(\mathrm{~s}, 3 \mathrm{H}, \mathrm{Al}-\mathrm{CH}_{3}\right),-0.35\left(\mathrm{~s}, 3 \mathrm{H}, \mathrm{Al}-\mathrm{CH}_{3}\right)$ ppm. ${ }^{13} \mathrm{C}\left\{{ }^{1} \mathrm{H}\right\}$ NMR from ${ }^{1} \mathrm{H}^{13} \mathrm{C}$ HSQC and HMBC $(126 \mathrm{MHz}$, $\mathrm{C}_{6} \mathrm{D}_{6}, 26{ }^{\circ} \mathrm{C}$ ) $\delta=152.3$ (quin- $C$ ), 150.1 (quin- $C$ ), 145.1 (quin- $C$ ), 142.2 (Ar), 140.2 (Ar), 138.4 (Ar), 137.3 (Ar), 139.5 (quin- $C$ ), 128.6 (Ar, quin- $C$, overlapping with solvent signal), 126.4 (Ar, quin- $C$ ), 124.6 (Ar), 124.0 (quin- $C$ ), 122.5 (quin- $C$ ), 121.0 (quin- $C$ ), 119.2 (Cp), 117.4 (Cp), $38.8\left(\mathrm{CH}_{3}\right), 37.9\left(C\left(\mathrm{CH}_{3}\right)_{3}\right), 34.9\left(C\left(\mathrm{CH}_{3}\right)_{2}\right), 34.2$ $\left(C\left(\mathrm{CH}_{3}\right)_{3}\right), 32.4\left(\mathrm{CH}_{3}\right), 31.9\left(\mathrm{C}\left(\mathrm{CH}_{3}\right)_{3}\right), 31.5\left(\mathrm{C}\left(\mathrm{CH}_{3}\right)_{3}\right), 29.4\left(\mathrm{CH}_{2}\right)$, $28.8\left(\mathrm{Al}-\mathrm{CH}_{3}\right), 0.9\left(\mathrm{Lu}-\mathrm{CH}_{3}\right),-9.2\left(\mathrm{Al}-\mathrm{CH}_{3}\right) \mathrm{ppm}$. DRIFT $(\mathrm{KBr})$ : $3394 \mathrm{vw}(\mathrm{NH}), 3348 \mathrm{vw}, 3045 \mathrm{vw}, 2951 \mathrm{vs}, 2902 \mathrm{~s}, 2865 \mathrm{~s}, 2754 \mathrm{w}$, $1603 \mathrm{vw}, 1586 \mathrm{vw}, 1506 \mathrm{~m}, 1475 \mathrm{w}, 1467 \mathrm{w}, 1423 \mathrm{~s}, 1396 \mathrm{w}, 1362 \mathrm{w}$, $1334 \mathrm{vw}, 1303 \mathrm{vw}, 1281 \mathrm{vw}, 1261 \mathrm{w}, 1237 \mathrm{w}, 1223 \mathrm{~m}, 1183 \mathrm{w}, 1159 \mathrm{w}$, 1119m, 841w, 829w, 821w, 806m, 788m, 776m, 757m, 738w, $699 \mathrm{~m}, 687 \mathrm{~m}, 656 \mathrm{w}, 648 \mathrm{w}, 626 \mathrm{vw} \mathrm{cm} \mathrm{cm}^{-1}$. Elemental analysis calcd (\%) for $\mathrm{C}_{39} \mathrm{H}_{56} \mathrm{AlLuN}_{2}$ (754.82 $\mathrm{g} \mathrm{mol}^{-1}$ ): C 62.06, H 7.48, N 3.71; found: $\mathrm{C}$ 60.53, H 5.92, N 3.72. Multiple attempts to obtain a better microanalysis failed.

$\mathbf{C p}^{\mathrm{Q}} \mathbf{Y M e}[\mathbf{N H}(\mathbf{A d})]\left(\mathrm{AlMe}_{3}\right)$ (7). A solution of 1-adamantylamine (30 $\mathrm{mg}, 0.20 \mathrm{mmol}$ ) in toluene $(2 \mathrm{~mL}$ ) was added to a solution of $\mathrm{Cp}^{\mathrm{Q}} \mathrm{Y}\left(\mathrm{AlMe}_{4}\right)_{2}(51 \mathrm{mg}, 0.10 \mathrm{mmol})$ in toluene $(1 \mathrm{~mL})$. The resulting yellow-brown solution was stirred for $1 \mathrm{~h}$ at ambient temperature, then dried under reduced pressure, washed with $n$-hexane $(2 \times$ $2 \mathrm{ml}$ ), and dried in vacuo (57 $\mathrm{mg}, 0.10 \mathrm{mmol}$, quant.). Crystallization from a toluene- $n$-hexane solution at $-35{ }^{\circ} \mathrm{C}$ afforded yellow crystals of 7 suitable for X-ray diffraction analysis. ${ }^{1} \mathrm{H}$ NMR $\left(400 \mathrm{MHz}, \mathrm{C}_{6} \mathrm{D}_{6}\right.$, $26{ }^{\circ} \mathrm{C}$, TMS): $\delta=8.88$ (dd, $1 \mathrm{H},{ }^{3} J_{\mathrm{HH}}=4.9$ and $1.5 \mathrm{~Hz}$, quin- $H$ ), 7.36$7.33(\mathrm{~m}, 1 \mathrm{H}$, quin- $H), 7.29\left(\mathrm{dd}, 1 \mathrm{H},{ }^{3} J_{\mathrm{HH}}=6.0\right.$ and $2.7 \mathrm{~Hz}$, quin- $H$ ), 
7.11-7.10 (m, 1H, quin- $H$ ), $6.96(\mathrm{~m}, 1 \mathrm{H}$, quin- $H), 6.57$ (dd, $1 \mathrm{H}$, ${ }^{3} J_{\mathrm{HH}}=8.3$ and $5.0 \mathrm{~Hz}$, quin- $\left.H\right), 2.28\left(\mathrm{~d}, 6 \mathrm{H},{ }^{3} \mathrm{~J}_{\mathrm{HH}}=2.2 \mathrm{~Hz}, \mathrm{CH}_{2}\right.$ Ad), 2.20 (s, 6H, $\left.\mathrm{CH}_{3} \mathrm{Cp}\right), 2.14(\mathrm{~m}, 3 \mathrm{H}, \mathrm{CH} \mathrm{Ad}), 2.11(\mathrm{~s}, 1 \mathrm{H}, \mathrm{NH})$, 1.79-1.61 (m, 6H, $\left.\mathrm{CH}_{2} \mathrm{Ad}\right), 1.78\left(\mathrm{~s}, 6 \mathrm{H}, \mathrm{CH}_{3} \mathrm{Cp}\right),-0.06(\mathrm{~d}, 12 \mathrm{H}$, $\left.{ }^{2} J_{\mathrm{YH}}=1.5 \mathrm{~Hz}, \mathrm{Y}-\mathrm{CH}_{3}\right) \cdot{ }^{13} \mathrm{C} \mathrm{NMR}\left(126 \mathrm{MHz}, \mathrm{C}_{6} \mathrm{D}_{6}, 26{ }^{\circ} \mathrm{C}\right) \delta=153.0$ (quin- $C$ ), 150.1 (quin- $C$ ), 139.9 (quin- $C$ ), 135.5 (quin- $C$ ), 133.0 (quin- $C$ ), 129.4 (quin- $C$ ), 127.0 ( $C \mathrm{Cp}$ ), $121.9\left(\mathrm{CCH}_{3} \mathrm{Cp}\right)$, $121.4\left(\mathrm{CCH}_{3} \mathrm{Cp}\right), 121.3$ (quin- $\left.\mathrm{C}\right), 58.3\left(\mathrm{NC}\left(\mathrm{CH}_{2}\right)_{3}(\mathrm{CH})_{3}\left(\mathrm{CH}_{2}\right)_{3}\right)$, $49.5\left(\mathrm{NC}\left(\mathrm{CH}_{2}\right)_{3}(\mathrm{CH})_{3}\left(\mathrm{CH}_{2}\right)_{3}\right), 37.0\left(\mathrm{NC}\left(\mathrm{CH}_{2}\right)_{3}(\mathrm{CH})_{3}\left(\mathrm{CH}_{2}\right)_{3}\right), 31.8$ $\left(\mathrm{NC}\left(\mathrm{CH}_{2}\right)_{3}(\mathrm{CH})_{3}\left(\mathrm{CH}_{2}\right)_{3}\right), 13.2\left(\mathrm{CH}_{3} \mathrm{Cp}\right), 12.7\left(\mathrm{CH}_{3} \mathrm{Cp}\right), 3.8\left(\mathrm{CH}_{3}\right.$, $\left.\mathrm{Al}\left(\mathrm{CH}_{3}\right)_{3}\right)$ ppm. DRIFT (KBr): 3048vw, 2907vs, 2847m, 1584vw, $1558 \mathrm{vw}, 1540 \mathrm{vw}, 1507 \mathrm{~m}, 1490 \mathrm{w}, 1472 \mathrm{w}, 1456 \mathrm{w}, 1436 \mathrm{w}, 1419 \mathrm{w}$, $1366 \mathrm{w}, 1301 \mathrm{w}, 1235 \mathrm{w}, 1184 \mathrm{w}, 1130 \mathrm{vw}, 1090 \mathrm{vw}, 1067 \mathrm{w}, 1023 \mathrm{vw}$, 985vw, 968vw, 929w, 841vw, 822w, 790m, 760w, 732m, 691vs, $577 \mathrm{w}, 471 \mathrm{w}, 419 \mathrm{vw} \mathrm{cm}^{-1}$. Elemental analysis calcd (\%) for $\mathrm{C}_{32} \mathrm{H}_{46} \mathrm{AlN}_{2} \mathrm{Y}$ (574.61 $\mathrm{g} \mathrm{mol}^{-1}$ ): C 66.89, H 8.07, N 4.88; found: $\mathrm{C} 65.33, \mathrm{H} 7.48, \mathrm{~N} 4.12$. Multiple attempts to obtain a better microanalysis failed.

$\mathbf{A l M e}_{3}\left(\mathbf{H}_{2} \mathbf{N A d}\right)$ (8). To a solution of 1-adamantylamine (47 mg, $0.31 \mathrm{mmol})$ in toluene $(2 \mathrm{~mL})$ trimethylaluminium $(23 \mathrm{mg}$, $0.31 \mathrm{mmol}$ ) was added. The colourless solution was stirred at ambient temperature for $1 \mathrm{~h}$ and then dried under reduced pressure (68 mg, $0.31 \mathrm{mmol}$, quant., 77\% crystalline yield). Crystallization from a toluene- $n$-hexane solution at $-35{ }^{\circ} \mathrm{C}$ afforded colourless crystals. ${ }^{1} \mathrm{H}$ NMR $\left(500 \mathrm{MHz}, \mathrm{C}_{6} \mathrm{D}_{6}, 26{ }^{\circ} \mathrm{C}\right.$, TMS): $\delta=1.68$ (s br, 3H, NC( $\left.\left(\mathrm{CH}_{2}\right)_{3}(\mathrm{CH})_{3}\left(\mathrm{CH}_{2}\right)_{3}\right), 1.59\left(\mathrm{~s} \mathrm{br}, \mathrm{NH}_{2}\right)$, 1.32-1.22 (m, 6H, NC( $\left.\left(\mathrm{CH}_{2}\right)_{3}(\mathrm{CH})_{3}\left(\mathrm{CH}_{2}\right)_{3}\right), 1.20\left(\mathrm{~d}, 6 \mathrm{H},{ }^{3} J_{\mathrm{HH}}=2.5\right.$ $\left.\mathrm{Hz}, \mathrm{NC}\left(\mathrm{CH}_{2}\right)_{3}(\mathrm{CH})_{3}\left(\mathrm{CH}_{2}\right)_{3}\right),-0.36\left(\mathrm{~s}, 9 \mathrm{H}, \mathrm{Al}\left(\mathrm{CH}_{3}\right)_{3}\right) \mathrm{ppm} .{ }^{13} \mathrm{C}$ NMR $\left(126 \mathrm{MHz}, \mathrm{C}_{6} \mathrm{D}_{6}, 26{ }^{\circ} \mathrm{C}\right) \delta=52.1\left(\mathrm{NC}\left(\mathrm{CH}_{2}\right)_{3}(\mathrm{CH})_{3}\left(\mathrm{CH}_{2}\right)_{3}\right)$, $43.6\left(\mathrm{NC}\left(\mathrm{CH}_{2}\right)_{3}(\mathrm{CH})_{3}\left(\mathrm{CH}_{2}\right)_{3}\right), 35.9\left(\mathrm{NC}\left(\mathrm{CH}_{2}\right)_{3}(\mathrm{CH})_{3}\left(\mathrm{CH}_{2}\right)_{3}\right), 29.9$ $\left(\mathrm{NC}\left(\mathrm{CH}_{2}\right)_{3}(\mathrm{CH})_{3}\left(\mathrm{CH}_{2}\right)_{3}\right),-5.7\left(\mathrm{Al}\left(\mathrm{CH}_{3}\right)_{3}\right)$. DRIFT IR (KBr): $3262 \mathrm{~m}$, $3214 \mathrm{~m}, 3117 \mathrm{vw}, 2910 \mathrm{vs}, 2851 \mathrm{~s}, 1570 \mathrm{~m}, 1455 \mathrm{~m}, 1363 \mathrm{~m}, 1352 \mathrm{w}$, $1319 \mathrm{w}, 1298 \mathrm{w}, 1284 \mathrm{w}, 1206 \mathrm{~m}, 1182 \mathrm{~m}, 1169 \mathrm{~s}, 1151 \mathrm{~s}, 1102 \mathrm{~m}$, $1087 \mathrm{~s}, 1042 \mathrm{w}, 982 \mathrm{w}, 936 \mathrm{w}, 922 \mathrm{w}, 815 \mathrm{w}, 711 \mathrm{vs}, 646 \mathrm{w}, 620 \mathrm{~m}$, $596 \mathrm{~m}, 567 \mathrm{w}, 526 \mathrm{w} \mathrm{cm}{ }^{-1}$. Elemental analysis calcd (\%) for $\mathrm{C}_{13} \mathrm{H}_{26} \mathrm{AlN}$ (223.33 $\mathrm{g} \mathrm{mol}^{-1}$ ): C 69.91, H 11.73, N 6.27; found: C 69.84, H 10.97, N 6.41. Multiple attempts to obtain a better microanalysis failed.

$\mathrm{X}$-ray crystallography and crystal structure determination of $2 \mathrm{a}$, $3,4,5,7$, and 8

Crystals of $2 \mathbf{a}$ and $\mathbf{3}$ were grown using standard techniques from saturated solutions using $n$-hexane or $n$-hexane-toluene $\left(4,5,7\right.$ and 8) at $-40{ }^{\circ} \mathrm{C}$. Suitable crystals for X-ray structure analyses were selected in a glovebox and coated with Parabar 10312 and fixed on a nylon loop/glass fiber.

X-ray data for 3 were collected on a Bruker AXS TXS rotating anode instrument using a Pt 135 CCD detector and for 4, 7 and 8 on a Bruker APEX DUO instrument equipped with an $\mathrm{I} \mu \mathrm{S}$ microfocus sealed tube and QUAZAR optics for $\mathrm{MoK}_{\alpha}$ radiation $(\lambda=0.71073 \AA$ A $)$. Data for compounds $2 \mathbf{a}$ and 5 were collected on a Bruker SMART APEX II instrument equipped with a fine focus sealed tube and a graphite monochromator using $\mathrm{MoK}_{\alpha}$ radiation $(\lambda=0.71073 \AA)$. The Data collection strategy was determined using $\mathrm{COSMO}^{38}$ employing $\omega$ - and $\phi$ scans. Raw data were processed using APEX $^{38}$ and SAINT, ${ }^{38}$ corrections for absorption effects were applied using SADABS. ${ }^{38}$ The structure was solved by direct methods and refined against all data by full-matrix leastsquares methods on $F^{2}$ using SHELXTL ${ }^{38}$ and ShelXle. ${ }^{39}$ All Graphics were produced employing ORTEP- $3^{40}$ and POV-Ray. ${ }^{41}$ Further details of the refinement and crystallographic data are listed in Table S1 (ESI $\dagger$ ) and in the CIF files. CCDC 1055068-1055073.

\section{Acknowledgements}

We are grateful to the German Science Foundation for support (Grant: AN 238/15-1).

\section{Notes and references}

1 (a) S. Arndt and J. Okuda, Chem. Rev., 2002, 102, 1953; (b) M. Zimmermann and R. Anwander, Chem. Rev., 2010, 110, 6194.

2 (a) O. Tardif, M. Nishiura and Z. Hou, Organometallics, 2003, 22, 1171; (b) D. Cui, O. Tardif and Z. Hou, J. Am. Chem. Soc., 2004, 126, 1312; (c) M. Nishiura and Z. Hou, Nat. Chem., 2010, 2, 257; (d) M. Nishiura, J. Baldamus, T. Shima, K. Mori and Z. Hou, Chem. - Eur. J., 2011, 17, 5033; (e) T. Shima, M. Nishiura and Z. Hou, Organometallics, 2011, 30, 2513.

3 (a) K. Beckerle and J. Okuda, Syndiotactic Polystyrene, John Wiley \& Sons, Inc., 2009, pp. 125-139; (b) X. Xu, Y. Chen and J. Sun, Chem. - Eur. J., 2009, 15, 846; (c) Z. Zhang, D. Cui, B. Wang, B. Liu and Y. Yang, in Molecular Catalysis of RareEarth Elements, ed. P. W. Roesky, Springer, Berlin, Heidelberg, 2010, pp. 49-108; (d) Z. Jian, S. Tang and D. Cui, Chem. - Eur. J., 2010, 16, 14007; (e) Z. Jian, D. Cui and Z. Hou, Chem. - Eur. J., 2012, 18, 2674; $(f)$ Y. Pan, W. Rong, Z. Jian and D. Cui, Macromolecules, 2012, 45, 1248; $(g)$ Y. Luo, S. Chi and J. Chen, New J. Chem., 2013, 37, 2675.

4 R. Anwander, M. G. Klimpel, H. M. Dietrich, D. J. Shorokhov and W. Scherer, Chem. Commun., 2003, 1008.

5 (a) M. Zimmermann, K. Törnroos and R. Anwander, Angew. Chem., Int. Ed., 2008, 47, 775; (b) M. Zimmermann, K. W. Törnroos, H. Sitzmann and R. Anwander, Chem. - Eur. J., 2008, 14, 7266; (c) M. Zimmermann, J. Volbeda, K. W. Törnroos and R. Anwander, C. R. Chim., 2010, 13, 651.

6 D. Robert, T. P. Spaniol and J. Okuda, Eur. J. Inorg. Chem., 2008, 2801.

7 H. H. Brintzinger, D. Fischer, R. Mülhaupt, B. Rieger and R. M. Waymouth, Angew. Chem., Int. Ed. Engl., 1995, 34, 1143.

8 H. M. Dietrich, K. W. Törnroos, E. Herdtweck and R. Anwander, Organometallics, 2009, 28, 6739.

9 (a) H. M. Dietrich, C. Zapilko, E. Herdtweck and R. Anwander, Organometallics, 2005, 24, 5767; (b) A. Fischbach, E. Herdtweck and R. Anwander, Inorg. Chim. Acta, 2006, 359, 4855; (c) E. L. Roux, Y. Liang, K. W. Törnroos, F. Nief and R. Anwander, Organometallics, 2012, 31, 6526.

10 H. M. Dietrich, H. Grove, K. W. Törnroos and R. Anwander, J. Am. Chem. Soc., 2006, 128, 1458.

11 (a) H. M. Dietrich, K. W. Törnroos and R. Anwander, J. Am. Chem. Soc., 2006, 128, 9298; (b) W.-X. Zhang, Z. Wang, 
M. Nishiura, Z. Xi and Z. Hou, J. Am. Chem. Soc., 2011, 133, 5712 .

12 In 1979, Schumann et al. reported on the synthesis of lutetium and erbium alkylidenes, $[\mathrm{Li}]\left[\mathrm{Lu}\left(\mathrm{CH}_{2} \mathrm{SiMe}_{3}\right)_{2}\left(\mathrm{CHSiMe}_{3}\right)\right]$ and $\left[\mathrm{Er}\left(\mathrm{CH}_{2} \mathrm{SiMe}_{3}\right)\left(\mathrm{CHSiMe}_{3}\right)\right]_{x}$ : H. Schumann and J. Müller, J. Organomet. Chem., 1979, 169, C1.

13 D. Schädle, C. Schädle, K. W. Törnroos and R. Anwander, Organometallics, 2012, 31, 5101.

14 C. Schädle, D. Schädle, K. Eichele and R. Anwander, Angew. Chem., Int. Ed., 2013, 52, 13238.

15 D. Schädle, C. Maichle-Mössmer, C. Schädle and R. Anwander, Chem. - Eur. J., 2014, 21, 662.

16 D. Schädle, M. Meermann-Zimmermann, C. Schädle, C. Maichle-Mössmer and R. Anwander, Eur. J. Inorg. Chem., 2015, 1334.

17 J. C. Gordon, G. R. Giesbrecht, D. L. Clark, P. J. Hay, D. W. Keogh, R. Poli, B. L. Scott and J. G. Watkin, Organometallics, 2002, 21, 4726.

18 (a) W. J. Evans, M. A. Ansari, J. W. Ziller and S. I. Khan, Inorg. Chem., 1996, 35, 5435; (b) H.-S. Chan, H.-W. Li and Z. Xie, Chem. Commun., 2002, 652.

19 (a) L. H. Gade and P. Mountford, Coord. Chem. Rev., 2001, 216-217, 65; (b) A. P. Duncan and R. G. Bergman, Chem. Rec., 2002, 2, 431.

20 (a) G. R. Giesbrecht and J. C. Gordon, Dalton Trans., 2004, 2387; (b) O. T. Summerscales and J. C. Gordon, RSC Adv., 2013, 3, 6682.

21 (a) P. Mountford, Chem. Commun., 1997, 2127; (b) S. R. Dubberley, A. Friedrich, D. A. Willman, P. Mountford and U. Radius, Chem. - Eur. J., 2003, 9, 3634; (c) S. R. Dubberley, S. Evans, C. L. Boyd and P. Mountford, Dalton Trans., 2005, 1448; (d) N. Adams, H. R. Bigmore, T. L. Blundell, C. L. Boyd, S. R. Dubberley, A. J. Sealey, A. R. Cowley, M. E. G. Skinner and P. Mountford, Inorg. Chem., 2005, 44, 2882; (e) A. R. Fout, U. J. Kilgore and D. J. Mindiola, Chem. - Eur. J., 2007, 13, 9428; $(f)$ A. D. Schwarz, A. J. Nielson, N. Kaltsoyannis and P. Mountford, Chem. Sci., 2012, 3, 819.

22 (a) L. K. Knight, W. E. Piers, P. Fleurat-Lessard, M. Parvez and R. McDonald, Organometallics, 2004, 23, 2087; (b) L. K. Knight, W. E. Piers and R. McDonald, Organometallics, 2006, 25, 3289; (c) R. K. Thomson, M. J. Monreal, J. D. Masuda, B. L. Scott and J. L. Kiplinger, J. Organomet. Chem., 2011, 696, 3966.
23 A. A. Karpov, A. V. Cherkasov, G. K. Fukin, A. S. Shavyrin, L. Luconi, G. Giambastiani and A. A. Trifonov, Organometallics, 2013, 32, 2379.

24 T. M. Cameron, J. C. Gordon and B. L. Scott, Organometallics, 2004, 23, 2995.

25 (a) M. A. Busch, R. Harlow and P. L. Watson, Inorg. Chim. Acta, 1987, 140, 15; (b) W. J. Evans, L. R. Chamberlain, T. A. Ulibarri and J. W. Ziller, J. Am. Chem. Soc., 1988, 110, 6423.

26 C. Cui, A. Shafir, J. A. R. Schmidt, A. G. Oliver and J. Arnold, Dalton Trans., 2005, 1387.

27 (a) E. Lu, Y. Li and Y. Chen, Chem. Commun., 2010, 46, 4469; (b) E. Lu, J. Chu, Y. Chen, M. V. Borzov and G. Li, Chem. Commun., 2011, 47, 743; (c) W. Rong, J. Cheng, Z. Mou, H. Xie and D. Cui, Organometallics, 2013, 32, 5523.

28 J. Zhou, J. Chu, Y. Zhang, G. Yang, X. Leng and Y. Chen, Angew. Chem., Int. Ed., 2013, 52, 4243.

29 (a) R. Litlabø, M. Zimmermann, K. Saliu, J. Takats, K. W. Törnroos and R. Anwander, Angew. Chem., Int. Ed., 2008, 47, 9560; (b) M. Zimmermann, J. Takats, G. Kiel, K. W. Törnroos and R. Anwander, Chem. Commun., 2008, 612.

30 M. Zimmermann, K. W. Törnroos and R. Anwander, Angew. Chem., Int. Ed., 2007, 46, 3126.

31 W. J. Evans, J. M. Perotti and J. W. Ziller, J. Am. Chem. Soc., 2005, 127, 3894.

32 L. N. Jende, C. Maichle-Mössmer and R. Anwander, Chem. - Eur. J., 2013, 19, 16321.

33 R. Litlabø, M. Enders, K. W. Törnroos and R. Anwander, Organometallics, 2010, 29, 2588.

34 M. F. Lappert, J. Holton, D. G. H. Ballard, R. Pearce, J. L. Atwood and W. E. Hunter, J. C. S. Chem. Commun., 1976, 480.

35 D. A. Atwood and D. Rutherford, Main Group Chem., 1996, $1,431$.

36 D. J. Beetstra, A. Meetsma, B. Hessen and J. H. Teuben, Organometallics, 2003, 22, 4372.

37 M. Enders, R. Rudolph and H. Pritzkow, Chem. Ber., 1996, 129, 459.

38 G. M. Sheldrick, Acta Crystallogr., Sect. C: Struct. Chem., 2015, 71, 3.

39 C. B. Hübschle, G. M. Sheldrick and B. Dittrich, J. Appl. Crystallogr., 2011, 44, 1281.

40 L. J. Farrugia, J. Appl. Crystallogr., 2012, 45, 849.

41 POV-Ray v. 3.6, Persistence of Vision Pty. Ltd., Williamstown, Victoria, Australia, 2004, http://www.povray.org/. 